\title{
Review \\ COVID-19 Diagnostic Strategies Part II: Protein-Based Technologies
}

\author{
Tina Shaffaf ${ }^{1,2}$ and Ebrahim Ghafar-Zadeh ${ }^{1,2,3, *(D)}$ \\ 1 Biologically Inspired Sensors and Actuators Laboratory (BioSA), York University, \\ Toronto, ON M3J1P3, Canada; tshaffaf@yorku.ca \\ 2 Department of Biology, Faculty of Science, York University, Toronto, ON M3J1P3, Canada \\ 3 Department of Electrical Engineering and Computer Science, Lassonde School of Engineering, \\ York University, Toronto, ON M3J1P3, Canada \\ * Correspondence: egz@cse.yorku.ca
}

check for updates

Citation: Shaffaf, T.; Ghafar-Zadeh E. COVID-19 Diagnostic Strategies Part II: Protein-Based Technologies. Bioengineering 2021, 8, 54. https:// doi.org/10.3390/bioengineering 8050054

Academic Editor: Rajesh Naik

Received: 9 March 2021

Accepted: 22 April 2021

Published: 28 April 2021

Publisher's Note: MDPI stays neutral with regard to jurisdictional claims in published maps and institutional affiliations.

Copyright: (c) 2021 by the authors. Licensee MDPI, Basel, Switzerland. This article is an open access article distributed under the terms and conditions of the Creative Commons Attribution (CC BY) license (https:// creativecommons.org/licenses/by/ $4.0 /)$.

\begin{abstract}
After the initiation of the current outbreak, humans' lives have been profoundly impacted by COVID-19. During the first months, no rapid and reliable detecting tool was readily available to sufficiently respond to the requirement of massive testing. In this situation, when the development of an effective vaccine requires at least a few months, it is crucial to be prepared by developing and commercializing affordable, accurate, rapid and adaptable biosensors not only to fight Severe Acute Respiratory Syndrome Coronavirus 2 (SARS-CoV-2) but also to be armed to avoid the pandemic in the earliest stages in the future. The COVID-19 diagnostic tools are categorized into two main groups of Nucleic Acid (NA)-based and protein-based tests. To date, nucleic acid-based detection has been announced as the gold-standard strategy for coronavirus detection; however, protein-based tests are promising alternatives for rapid and large-scale screening of susceptible groups. In this review, we discuss the current protein-based biosensing tools, the research advances and the potential protein-detecting strategies for COVID-19 detection. This narrative review aims to highlight the importance of the diagnostic tests, encourage the academic research groups and the companies to eliminate the shortcomings of the current techniques and step forward to mass-producing reliable point-of-care (POC) and point-of-need (PON) adaptable diagnostic tools for large-scale screening in the future outbreaks.
\end{abstract}

Keywords: COVID-19 detection; protein-based tests; SARS-CoV-2; point-of-care (POC) detection; serological tests; antigenic tests; rapid diagnostic tests; LFIA; ELISA; protein microarray

\section{Introduction}

The spread of the Severe Acute Respiratory Syndrome Coronavirus 2 (SARS-CoV-2) has resulted in a life-threatening novel respiratory disease worldwide [1]. By 5 March 2021, the total number of the confirmed coronavirus disease 2019 (COVID-19) cases and the deaths have been reported as $115,289,961$ and 2,564,560, respectively [2]. The main concern regarding the prompt spread of this virus is that a considerable portion of the infected cases do not experience the typical known symptoms of fever, fatigue and dry cough in the first stage and only symptomatic cases of COVID-19 are being identified and isolated [3]. Such pre-symptomatic or asymptomatic cases are not informed of the being carriers and accelerate the community spread by their presence in the society. To date, a few companies have developed vaccines to protect people from the infection caused by COVID-19. Although these vaccines have successfully received the U.S. Food and Drug Administration's (FDA) approval, their long-term effects, side effects, and the effectiveness of them are some other challenges requiring more time and evaluation after the initiation of vaccination in the real world. Considering the serious and fatal effects of COVID-19, reliable rapid, accurate and affordable diagnostic tests are urgently required not only 
for detection of the infection in the earliest stages but also to monitor the disease and conducting convalescence studies to control this outbreak.

Based on FIND, as of March 5, at least 1130 diagnostic tests have been submitted to various regulatory organizations in different countries, about 1030 tests have received emergency authorization and are manufactured [4]. Two main diagnostic categories are employed for sensing the coronavirus 2019; the first group targets viral nucleic acid and the second one captures specific polypeptides either in the virus structure or in the blood of the suspected people. The present article provides a narrative review to discuss the current protein-based technologies for COVID-19 detection and challenges associated with each technology. In the rest of the paper, Section 2 describes the structure of the coronavirus 2019 and the immune response to SARS-CoV-2 specific antigens, Section 3 explains both laboratory-based and rapid PC SARS-CoV-2 serological tests, Section 4 discusses antigenic tests, and the last section includes the potential protein-based strategies to be developed for COVID-19 detection in the future.

\section{SARS-COV-2 Virology}

The genetic material of the SARS-CoV-2 is an RNA including six open reading frames (ORFs) responsible for the production of the nucleocapsid $(\mathrm{N})$, spike $(\mathrm{S})$, membrane $(\mathrm{M})$ and a small envelope (E) structural protein subunits; the rest of the genes produce 16 functional proteins such as RNA dependent RNA polymerase (RdRP) and helicase [5]. N protein attaches to the coronavirus genetic RNA and forms nucleocapsid. Spike glycoproteins (S1 and S2 subdomains) are surface densely glycosylated proteins specifying the type of the infected host and are involved in various tendencies to different tissues [6]. Angiotensinconverting enzyme 2 (ACE2), expressed in human endothelial cells in the lung, intestine, heart and kidney, is a surface protein and a functional receptor for coronavirus [7]. This protein acts as a direct binding site for virus $S$ protein, the receptor-binding domain (RBD) of the S1 subunit of S protein directly contacts the ACE2 receptor with a high affinity and has crucial roles in attachment and fusion of the virus through the ACE2-containing host cells [8]. M protein has the main role in forming new virus particles and could insert some proteins from the host to the viral envelope [9]. The E protein is the smallest structural protein having roles in coronavirus assembly and pathogenesis [10]. The arrangement of these four proteins is different among coronaviruses, but their presence is critical for infectious characteristics of SARS-CoV-2. After the entry of the coronavirus into the human body, the immune system demonstrates a prompt defensive response to the viral antigens and produces specific antibodies to fight the disease [11]. The coronavirus is capable of inducing a variety of disease statuses from asymptomatic infection to mild and severe respiratory failures in some cases. The main symptoms associated with COVID-19 include fever, dry cough, shortness of breath and fatigue. In the COVID-19 cases, the SARS-CoV-2 induces the elevation of pro-inflammatory cytokines and eventually forms a cytokine storm in the patient's body, which probably damages the organs and cause death [12]. Clinical studies have proven that the SARS-CoV-2 infection is also capable of inducing cardiac injuries, kidney failure, acute renal, kidney, liver and cardiac injuries. It has been demonstrated that the average age of the incidence of severe COVID-19 associated with neutrophilia, leukocytosis and death is higher than the surviving patients, over 65 years old. By knowing these facts, identifying and considering these potential risk factors could help the physicians for a better prognosis and diagnosis [13,14].

From a diagnostic point of view, specific virus antigens or specific antibodies against these antigens are detectable in the specimens collected from COVID-19 positive patients e.g., respiratory swabs, saliva, blood, serum, stool and other types of samples [15]. Considering the guidance published by the World Health Organization (WHO), FDA and centers of disease control and prevention (CDC), nucleic acid (NA)-based tests are the main tests employed for detection of the virus in suspected cases and serological tests are mostly qualitative tools beneficial for confirmation of the reported result as supplementary tests together with other clinical data $[16,17]$. As the protein-based COVID-19 diagnostic 
strategies have demonstrated a broad range of accuracy, to measure the characteristics of each developed kit, i.e., sensitivity and specificity, their results are evaluated with a reference method. This reference panel is established by FDA and consists of standardized materials. The main technology for evaluation of the specific kits is Real-Time (RT)-PCR using nasopharyngeal samples. The related kits are distributed between the different companies, and they are requested to perform tests using both the reference RT-PCR kit and their developed device and report the results back to the FDA [18].

\section{Serodiagnosis of SARS-COV-2}

Serological tests have been serving as one of the main categories to detect infectious diseases over time by targeting the specific antibodies (Ab) or so-called immunoglobulins (Ig) secreted in the human body. These systemic immunoglobulin are secreted from white blood cells (WBCs) particularly B cells (lymphocytes) as protective proteins during the infection $[19,20]$. Each antibody contains four structural proteins Two heavy $(\mathrm{H})$ chains and two light (L) chains when the N-terminuses of all of the chains are the antigen-binding site, specific to a particular antigen and different from the other antibodies. There are different isotypes of antibodies including immunoglobulin M (IgM), IgG and IgA which are distinguished by their specific regions in their heavy chains C-terminus. IgG as the most frequent antibody is secreted in the blood (serum), IgM is another antibody isotype in the blood, while IgA is abundant in both blood and other liquids in the human body such as saliva and breast milk. The expression of the specific antibodies binding to SARS-CoV-2 antigens is upregulated after the viral infection [21]. More specifically, IgM experiences an elevated expression in the moderate phase of the disease until about week two of the infection and begins to decline and almost disappears until week seven, while $\operatorname{IgG}$ expression is upregulated in the late phase from weeks 2-3 and remains high even beyond seven weeks (the exact durations are unknown) [22,23]. IgM detection has low sensitivity in the early stage of infection, which results in requiring repeated sample-taking every day. On the other hand, IgG is not preferred for screening the infection, but for patients' followup, self-healing and convalescence status as well as the determination of the immune response of asymptomatic cases [24]. Compared with IgM and IgG, IgA has gained less attention for diagnostic purposes; however, the evidence suggests that IgA upregulation takes place earlier even before IgM and systematic studies on the IgA in COVID-19 patients are still lacking [25]. The first generations of the tests targeting SARS-CoV-2 antibodies applied SARS-CoV antigens to detect the SARS-CoV-2 specific Abs due to the absence of the specific antigens of the new coronavirus at that time. This problem was addressed after achieving more information regarding the new virus during the next months [26].

All of the serological assays rely on capturing specific antibodies in a mixture using an antibody-antigen attachment [27]. Based on the literature, the majority of the COVID-19 specific antibodies are against SARS-CoV-2 $\mathrm{N}$ antigen making them the most sensitive targets for serodiagnosis. The most specific antibodies are against the $\mathrm{S} 1$ domain of $\mathrm{S}$ protein. For this reason, S1 is suggested as the most specific viral target while S2 has demonstrated to have cross-reactions with SARS-CoV-1 specific antibodies. In the early days after infection, the sensitivity of serological tests is low and results in a false negative. The amounts of the antibodies are not high enough to be detected in the samples collected from the patients in the early phases of the infection, while, after about 10-15 days and in symptomatic cases, the tests demonstrate higher sensitivity and specificity to the desired antibodies [28]. It is noteworthy that the limitation of the serological tests that detect the specific antibodies is the probability of demonstrating cross-reaction due to the presence of pre-existing antibodies or for other reasons. Vaccination or prior infection with the SARS-CoV-2 could result in activating the immune system followed by secretion of longterm persistence of a portion of antibodies such as SARS-CoV-2 specific IgG [29]. The results of such tests strongly depend on affecting factors e.g., sample type, patient situation and disease phase at the time of the collecting sample. Generally, antibody tests are very informative and important owing to their ability for past infection detection, but they are 
not reliable for the early detection of COVID-19 in the first stages of the disease because seroconversion occurs after symptom appearance. These tests are more informative while performing for the evaluation of convalescence status, immune response and employed as screening tools for testing the rate of serosurvey and prevalence [30].

By the date, hundreds of serological tests have been developed and received FDA EUA approval to be performed for COVID-19 detection to target one specific $\mathrm{Ab}$ or a different combination of them in the blood or blood products of the suspected individuals either in a lab-based or in a POC setting [31]. Considering the fact that many of these technologies have been developed very recently, the provided information regarding the tests' performance and accuracy are mostly based on both the companies and the FDA reports. By passing of time and the availability of more reports, we will cover the clinical reports of these tests along with their applicability in the real world in our future research.

\subsection{Laboratory-Based Non-Isotopic Immunoassay (NIIA) Serological Tests}

Enzyme-linked immunoassays (EIA) are NIIA assays that are suitable for lab-based detection or measurement of specific antibodies in the blood and serve as the main strategies which regularly assist laboratory scientists for COVID-19 screening. Generally, the main drawbacks limiting the clinical application of the immunoassays are high costs, their complexity and long duration making them not applicable as a simple and rapid POC and near-patient tool [32].

EIA variants including particularly Chemiluminescence Immunoassays (CLIA) and Enzyme-linked immunosorbent assay (ELISA) are frequently being employed for COVID19 detection; they are also the routine serological methods for convalescence prediction and quantifying materials including antibodies and hormones. All of the immunoassays in this category take advantage of the affinity between antigens and specific antibodies with enzyme-based labels usually immobilized on the microplate surface [33].

\subsubsection{Chemiluminescence Immunoassays (CLIA)}

CLIA is one of the most popular immunoassays which utilizes chemiluminescent or light-emitting labels for the detection of biomolecules present in blood, serum or plasma in a total duration of about 1-2 h [34]. In this technology, recombinant antigens labelled with chemiluminescent materials or luminescent substances form complexes with the specific antibodies when the positive sample is introduced to the microwell, followed by instrument-based detection for light-emitting signal measurement [35]. CLIA assays benefit from the advantages of automation, requiring a low amount of antigen and shorter sampleto-result time compared with some other serological strategies. This technology is known as a sensitive method to detect the small amounts of proteins with a high throughput; however, there might be some problems during the measurement or compound solubility. The main drawbacks of this strategy are being complex and costly compared with other serological tests [33]. The proposed CLIA-based diagnostic tests for SARS-CoV-2 detection have mainly used viral $\mathrm{N}$ or S antigens or a combination of them [36]. Based on the literature, the RBD domain of $\mathrm{S}$ and $\mathrm{N}$ antigen are the most preferred choices to be used for the detection of $\operatorname{IgM} / \operatorname{IgG}$ or total antibody. The highest reported accuracy is related to the RBD-based CLIA detecting IgG antibody in the blood samples [37]. It should be highlighted that many factors such as the time of sample collection and disease phase affect the performance of these assays which might not be mentioned in the published articles. Although not being applicable in the POC setting, the main advantage of the fully automated versions of CLIA over rapid serological tests is the ability of high-throughput sample analysis [38].

Many researchers and manufacturers have developed diagnostic tests based on CLIA variants, electrochemiluminescence immunoassay (ECLIA) and chemiluminescent microparticle immunoassay (CMIA), to fight the current pandemic (Table 1). The main difference between ECLIA and CLIA is the chemiluminescence generation technique, electrochemical reactions in ECLIA and chemical reactions in CLIA. Infantino et al. evaluated 
the clinical accuracy of the Shenzhen YHLO Biotech CLIA kits for SARS-CoV-2 antibodies IgM and IgG. IgG demonstrated a lower cut-off for anti-SARS-CoV-2 antibodies [39]. Long and colleagues have studies IgM and IgG using a combination of $\mathrm{S}$ and $\mathrm{N}$ antigens in 363 samples from COVID-19 positive patients and observed a medium IgG- and IgM positive serostatus at day 13 after the symptom onset and a 100\% seroconversion for IgG at day 20 [40]. Cai et al. proposed a Peptide-based Magnetic CLIA (MCLIA) for serological detection of COVID-19 and evaluated it with 276 sera samples from confirmed COVID-19 patients. The positive rate was $71.4 \%$ for IgG and $57.2 \%$ for IgM [41]. Lin and colleagues developed a chemiluminescence-immunoassay method using magnetic beads and recombinant nucleocapsid antigen for the detection of COVID-19. The test obtained a sensitivity of $60.76 \%$ for IgM and $92.25 \%$ for IgG. The specificity of the test for IgM and IgG was $92.25 \%$ and $97.5 \%$, respectively. They concluded that IgG CLIA is more accurate compared with IgM CLIA and suitable to be performed with RT-PCR to improve clinical detection [42].

Another group employed the same assay with fewer specimens and reported low sensitivity of $48 \%$ but $100 \%$ specificity for the IgM test, while IgG detection illustrated $89 \%$ sensitivity and $91 \%$ specificity, respectively. By combining IgM and IgG testing, they achieved the highest accuracy for COVID-19 detection [43]. Ma et al. evaluated using RBD antigen and N antigen using CLIA and demonstrated a higher accuracy for the RBDbased CLIA detection. In addition, targeting IgA showed to be more sensitive and specific compared with IgM or IgG solely detection [37].

\subsubsection{Enzyme-Linked Immunosorbent Assay (ELISA)}

ELISA is one of the most frequently used methods for serological detection of the infection with about $1-5 \mathrm{~h}$. ELISA, as the manual version of the automated CLIA, is a microwell/plate-based assay employing immobilized capture antigen, and a secondary/tracer antigen which targets specific antibodies in the serum, plasma and/or whole blood samples [45], resulting in fluorescence or visible colour change in a chromogenic substrate by enzymatic activity qualitatively or quantitatively (Figure 1) $[45,46]$. The advantages of ELISA are being sensitive and specific, detecting both current and previous infection, lower costs compared with CLIA, and high-throughput, requiring simple facilities and determining selective isotype and antibody titers. ELISA has many capabilities such as being performed as a multiplexed or microarray-based test for parallel detection of various antibodies in a single sample [47]. On the other hand, some challenges such as sample preparation, requiring high sample volume, probability of false positives, antibody variability, manual procedures and high workload, probable cross-reactions along the duration of the tests have limited their applications, especially as rapid POC tests. Requiring trained personnel and delivery of the samples to the specialized labs make these tests even more time and labour-consuming and costly [33]. Although laboratories widely employ ELISA for coronavirus 2019 detection, only a few numbers of commercialized kits are based on this strategy which may be resulted from these limitations.

For ELISA-based COVID-19 detection, the researchers represent the immune response of the human body to the SARS-CoV-2 infection, indicating prior or recent infection. Based on the literature, IgM and IgG are recognized to be more upregulated compared to IgA and act as better targets in COVID-19 investigations. However, studies have demonstrated that IgA is also increased in response to SARS-CoV-2 infection and some tests developed to target IgA in blood or serum samples as well [48]. 
Table 1. Selected approved CLIA-based tests as Lab-based and high throughput COVID-19 detection strategies based on FDA Serology Test Performance [44].

\begin{tabular}{|c|c|c|c|c|c|c|c|}
\hline Company & Test & Technology & Target & Antigen & $\begin{array}{c}\text { Sensitivity (Day } 15 \\
\text { after Symptom Onset) }\end{array}$ & Specificity & Throughput \\
\hline Ortho Clinical Diagnostics, Inc. & $\begin{array}{c}\text { VITROS Immunodiagnostic } \\
\text { Products Anti-SARS-CoV-2 } \\
\text { Total Reagent Pack }\end{array}$ & CLIA & Total Antibody & $\mathrm{S}$ & $100 \%$ & $100 \%$ & $\begin{array}{l}150 \text { tests/h with one } \\
\text { result in } 48 \mathrm{~min}\end{array}$ \\
\hline Beckman Coulter, Inc. & Access SARS-CoV-2 IgG & \multirow{2}{*}{$\begin{array}{c}\text { Automated CLIA } \\
\text { Fully Automated } \\
\text { CLIA }\end{array}$} & $\operatorname{IgG}$ & $\mathrm{S}$ & $96.8 \%$ & $99.6 \%$ & 50-200 tests $/ \mathrm{h}$ \\
\hline Babson Diagnostics, Inc. & Babson Diagnostics aC19G1 & & $\operatorname{IgG}$ & S & $100 \%$ & $100 \%$ & 440 tests $/ \mathrm{h}$ \\
\hline Ortho Clinical Diagnostics, Inc. & $\begin{array}{c}\text { VITROS Immunodiagnostic } \\
\text { Products Anti-SARS-CoV-2 } \\
\text { IgG Reagent Pack }\end{array}$ & CLIA & $\operatorname{IgG}$ & $S$ & $90.0 \%$ & $100 \%$ & 150 tests $/ \mathrm{h}$ \\
\hline $\begin{array}{l}\text { Siemens Healthcare } \\
\text { Diagnostics Inc. }\end{array}$ & $\begin{array}{c}\text { ADVIA Centaur } \\
\text { SARS-CoV-2 Total (COV2T) }\end{array}$ & $\begin{array}{l}\text { Automated-Semi- } \\
\text { quantitative } \\
\text { CMIA }\end{array}$ & Total Antibody & $S$ & $100 \%$ & $99.8 \%$ & $\begin{array}{l}240 \text { samples } / \mathrm{h} \text { with one } \\
\text { result in } 18 \mathrm{~min}\end{array}$ \\
\hline $\begin{array}{l}\text { Siemens Healthcare } \\
\text { Diagnostics Inc. }\end{array}$ & $\begin{array}{c}\text { Atellica IM SARS-CoV-2 } \\
\text { Total (COV2T) }\end{array}$ & Automated CMIA & Total Antibody & $\mathrm{S}$ & $100 \%$ & $99.8 \%$ & $\begin{array}{l}440 \text { tests } / \mathrm{h} \text { with one } \\
\text { result in } 10 \mathrm{~min}\end{array}$ \\
\hline DiaSorin & $\begin{array}{c}\text { LIAISON SARS-CoV-2 } \\
\text { S1/S2 IgG }\end{array}$ & $\begin{array}{c}\text { Complex Automated } \\
\text { CLIA }\end{array}$ & $\operatorname{IgG}$ & $\mathrm{S}(\mathrm{S} 1 / \mathrm{S} 2)$ & $97.6 \%$ & $99.3 \%$ & $\begin{array}{l}170 \text { tests } / \mathrm{h} \text { and } 35 \mathrm{~min} \\
\text { time to first result }\end{array}$ \\
\hline Vibrant America Clinical Labs & Vibrant COVID-19 Ab Assay & CLIA & $\operatorname{IgM}$ and $\operatorname{IgG}$ & $\mathrm{S}$ and $\mathrm{N}$ & $98.1 \%$ & $98.6 \%$ & $24-36 \mathrm{~h}$ \\
\hline Diazyme Laboratories, Inc. & $\begin{array}{c}\text { Diazyme SARS-CoV-2 IgM } \\
\text { CLIA test }\end{array}$ & CLIA & $\operatorname{IgM}$ & $\mathrm{S}$ and $\mathrm{N}$ & $94.4 \%$ & $98.3 \%$ & 50 tests $/ \mathrm{h}$ \\
\hline Diazyme Laboratories, Inc. & $\begin{array}{c}\text { Diazyme DZ-Lite } \\
\text { SARS-CoV-2 IgG CLIA Kit }\end{array}$ & Automated CLIA & $\operatorname{IgG}$ & $\mathrm{S}$ and $\mathrm{N}$ & $100 \%$ & $97.4 \%$ & 50 tests $/ \mathrm{h}$ \\
\hline Roche Diagnostics & Elecsys Anti-SARS-CoV-2 & ECLIA & Total Antibody & $\mathrm{N}$ & $100 \%$ & $99.8 \%$ & 300 tests $/ \mathrm{h}$ \\
\hline Abbott Laboratories Inc. & Architect SARS-CoV-2 IgG & CMIA & IgG & $\mathrm{N}$ & $100 \%$ & $99.6 \%$ & 100 samples in $70 \mathrm{~min}$ \\
\hline Abbott Laboratories Inc. & Alinity i SARS-CoV-2 IgG & CMIA & $\operatorname{IgG}$ & $\mathrm{N}$ & $100 \%$ & $99.0 \%$ & $\begin{array}{l}4000 \text { tests in } 24 \mathrm{~h} \text {, with a } \\
29 \text { min time to first result }\end{array}$ \\
\hline
\end{tabular}




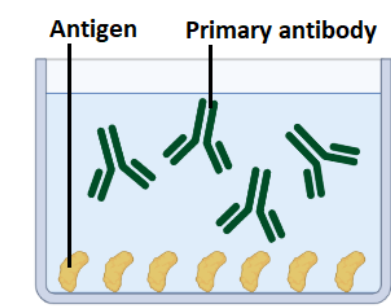

(1) Antibody-containing sample is added to the antigen-coated ELISA plate

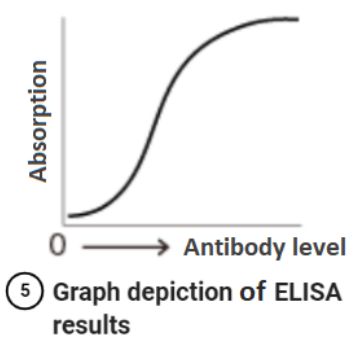

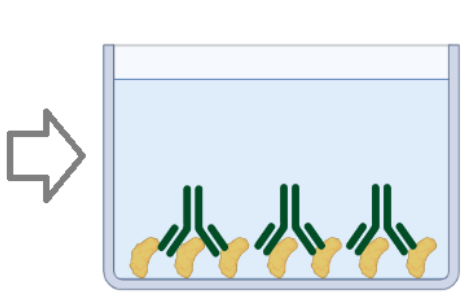

(2) The target antibodies bind to the antigens coated on the surface

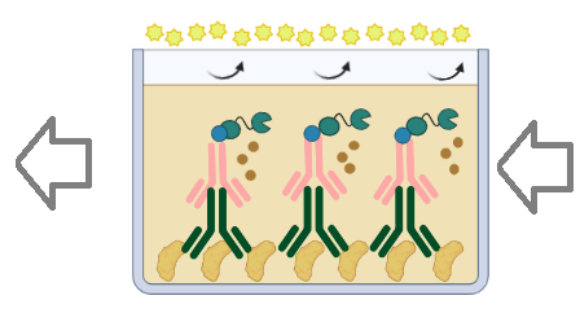

(5) Enzime reacts with the substrate and produces colour with a intensity directly related to the target antibody level

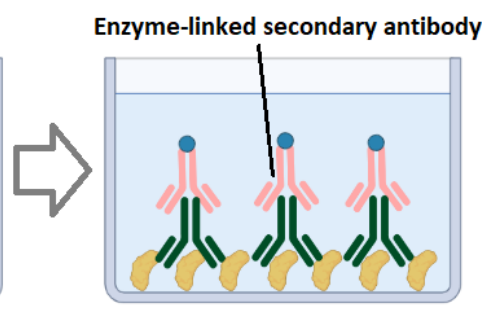

(3) Secondary Enzime-linked antibodies bind detection antibody

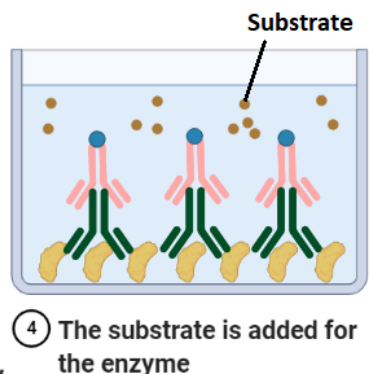
the enzyme

Figure 1. Schematic of ELISA technique for indirect detection of SARS-CoV-2. SARS-CoV-2 specific antibodies are added to the well and adhere to the immobilized viral antigens. Primary antibodies attach to the target antibodies, and a secondary enzyme-linked tracer antibody reacting with a chromogen is added and produces colour change. The intensity of the colour correlated with the concentration of the antigen in the sample.

Although a few numbers of the assays employ full-length $S$ antigen as capture molecules in the test, it is commonly referred to use specific shorter peptides from this protein such as RBD domain. A research group developed two different versions of ELISA assay for the detection of S-specific antibodies using full-length S protein and RBD domain. When evaluated the tests, the data revealed that the reactivity of both of the antigens was high, with a significantly higher reactivity for $S$ antigen [49]. Okba et al. also evaluated the effectiveness of $S$ antigen and its S1 and RBD domains using different ELISA kits. They observed that RBD and N proteins achieved the best results for the samples from mild patients and when they were tested using samples from the patient on day 14 after symptom onset, RBD ELISA had 100\% sensitivity for IgG and 94\% sensitivity for IgM, while, for $\mathrm{N}$ protein, the specificity of targeting $\operatorname{IgG}$ and IgM was $94 \%$ and $88 \%$ respectively. They also observed that, when the capture molecule is $\mathrm{S} 1$ and targets are IgA and IgG, IgA ELISA demonstrates a better sensitivity and IgG displayed a better specificity [50]. In another study, Zhang et al. simultaneously targeted IgG and IgM against SARS-CoV-2 and demonstrated that anti-S antibodies are more appropriate to be detected compared with anti-N antigens [51].

Companies such as Bio-Rad Laboratories, DRG Diagnostics GmbH, Euroimmun, IBL International and Epitope Diagnostics have developed manual ELISA tests for COVID-19 detection. Various FDA EUA approved, and CE marked ELISA kits, have been commercially available targeting $\operatorname{IgM}, \operatorname{IgG}, \operatorname{IgA}, \operatorname{IgG} / \operatorname{IgM}$ or total antibodies in the collected specimens, whose names and characteristics are listed in Table 2. Only one of these authorized kits has targeted total neutralizing antibodies against SARS-CoV-2 RBD in human serum and plasma using blocking ELISA [52]; CPass $^{\mathrm{TM}}$ SARS-CoV-2 Neutralization Antibody Detection Kit is a 96-well format ELISA test which has an unknown sensitivity, and cross-reactions may occur for various causes such as the pre-existing antibodies [53]. 
Table 2. Selected FDA EUA authorized Lab-based ELISA tests for COVID-19 detection [44].

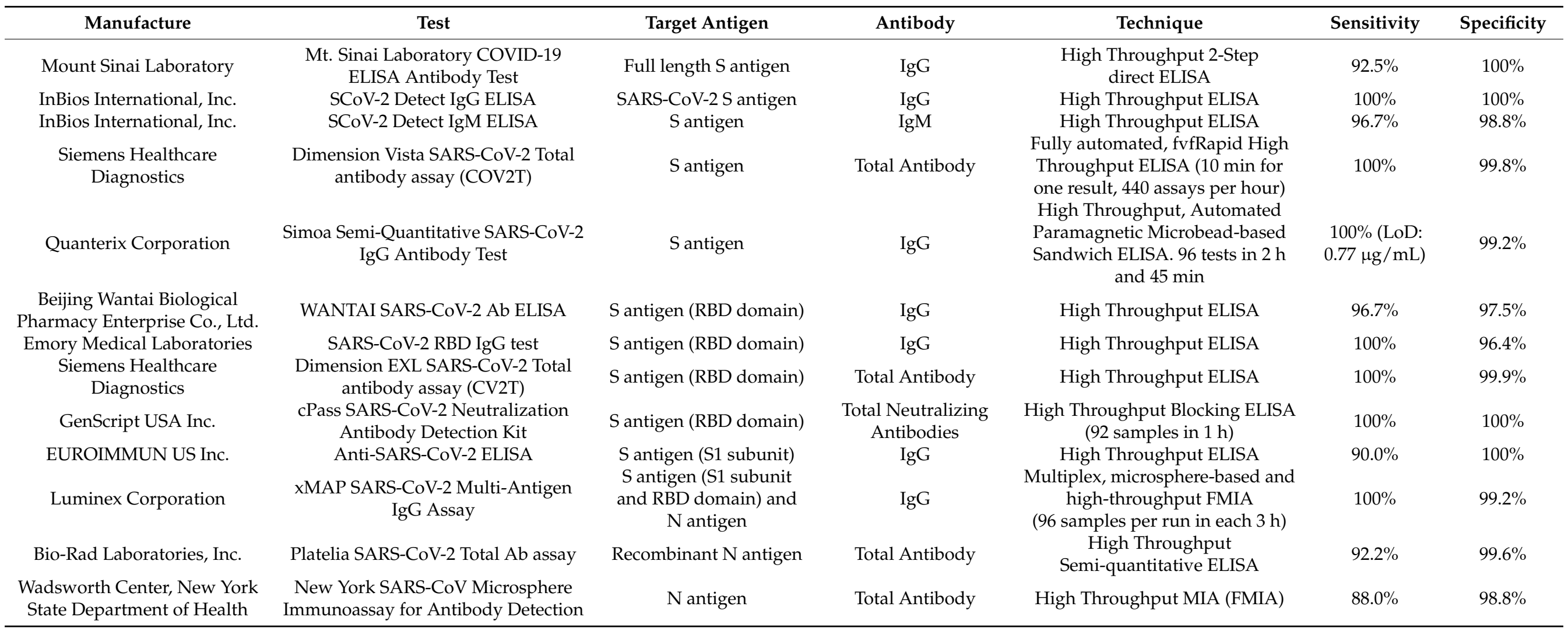


Lassaunière et al. validated three ELISAs with serum samples and demonstrated the best performance from Wantai SARS-CoV-2 Total Antibody ELISA with 100\% specificity and $90 \%$ sensitivity, Euroimmun IgA ELISA showed $93 \%$ specificity and 90 sensitivity and Euroimmun IgG ELISA displayed the lowest sensitivity of $65 \%$ with $96 \%$ specificity [54]. Beijing Wantai Total Ab ELISA is reported to achieve higher sensitivity (94.5\% claimed by manufacture) compared with Beijing Wantai IgM and IgG ELISAs with $83 \%$ and $65 \%$ sensitivities, respectively [28], which was similar to the lower sensitivity of $65 \%$ for Euroimmun IgG ELISA as well. It can be concluded that total antibody ELISA tests display a better performance with higher accuracy and less cross-react compared with IgG ELISA, IgM ELISA or IgA ELISA [54].

Microsphere Immunoassay (MIA) is one of the ELISA variants using fluorescent material-labelled secondary antibody and magnetic carboxylated microspheres-virus antigen particle conjugates for detection of the antibodies in serum [55]. This technique implements both flow cytometry and ELISA and includes two main parts. MIA is newer and more accurate than ELISA; however, it requires expensive instruments and materials and is usually more time-consuming [56]. In one research, semi-quantitative MIA (FDA approved) was evaluated. An important observation was that, using this technique, SARSCoV-2 antibodies were detected in $26.3 \%$ of the patients when they were at the hospital, but this number increased to $100 \%$ after 21 days from symptom initiation. Hence, this technique is reliable for the evaluation of immune response in convalescent and symptomatic patients but not for early detection of COVID-19 [57]. It is demonstrated that comparing MIA and ELISA are considerably more sensitive and specific than lateral flow immunoassays (LFIA) [55]. Conversely, Crook evaluated the sensitivity and specificity of two SARS-CoV-2 antibody tests using ELISA and LFIA and observed a higher sensitivity for LFIA devices compared with ELISA (65-85\% and $55-70 \%$ respectively) and $93-100 \%$ specificity for LFIA versus $95-100 \%$ specificity for the ELISA test [58]. Rosenberg et al. tried to estimate SARSCoV-2 cumulative incidence by conducting a developed and validated SARS-CoV-2 IgG MIA-based test. In summary, magnetic beads were coupled with viral $\mathrm{N}$ antigens. Labelled goat anti-human IgG secondary antibody was employed for microsphere-bound IgG antibodies detection using median fluorescence intensity (MFI). The test has $99.75 \%$ specificity and 87.9 sensitivity [59]. Fong et al. developed a microsphere-based antibody assay (MBA) for detection of anti-RBD and anti-S-specific IgGs and validated it using 294 serum samples. This test achieved $100 \%$ specificity for anti-NP IgG and $98.9 \%$ specificity for anti-RBD IgG. MBA seropositive rate for COVID-19 convalescence was 79.5\% for anti-RBD IgG and 89.8\% for anti-NP IgG with a shorter duration compared with EIA [60].

\subsection{Lab-Based Fluorescence Immunoassays (FIA)}

FIA is a quantitative fluorescent-labelled immunoassay, a biochemical technique that detects the attachment of the capture antibody and the desired analyte [61]. This technology employs a fluorescent material that emits energy or light as a fluorescent signal. In this technique, fluorescent dyes such as FITC provide the signal and a microplate fluorometer measures it [62]. Fluorescent microsphere immunoassay (FMIA) is used as a quantitative or semiquantitative method for COVID-19 diagnosis. Compared with ELISA, FMIA has the advantage of being more accurate and cost-effective, detects the infection using both serum and non-serum samples and there is no need for cycles of dilution for performing a semi-quantitative test [63]. This technology requires a small volume of sample and simultaneously detects multiple targets [64]. However, the number of developed tests using FMIA is lower than other techniques.

FMIA employs beads or microspheres (Luminex) coated with antigen, and the wells house hundreds of distinct sets of beads for the detection of unique antigens. Each microparticle is coloured with a unique combination of two various fluorescent dyes with various ratios as reporters. Additionally, two distinct lasers excite the beads during the test [65]. An FMIA-based test developed by Wadsworth Center, New York SARS-CoV Microsphere Immunoassay has successfully received FDA EUA authorization for antibody 
Detection. This test uses the full-length $\mathrm{N}$ protein as the target antigen for the detection of total antibodies. The sensitivity and specificity of the test are estimated $88.0 \%$ and $98.8 \%$, respectively, for performing the test on day 25 after the onset of the disease. The important fact is that the sensitivity will be lower for the tests at earlier days of the infection [66]. Another FDA-approved FMIA test is developed by Luminex Corporation, namely xMAP SARS-CoV-2 Multi-Antigen IgG Assay. This assay targets IgG antibodies against three different SARS-CoV-2 antigens including N, S1 and RBD polypeptides. The throughput of the test is 96 and reports the results in $3 \mathrm{~h}$ using plasma or serum samples. PPA for this assay for serum samples while using MAGPIX ${ }^{\circledR}\left(\mathrm{NxTAG}^{\circledR}\right.$-enabled) system is $71.4 \%$ and $96.2 \%$ for the samples collected on days $8-14$ and $>14$ from symptom onset, respectively, while the NPA is $100 \%$ [67].

GenBody, Inc. has developed a manual Colloidal Gold Nanoparticle-Based FIA-based immunoassay, GenBody FIA COVID-19 IgM/IgG, which detects IgG and IgM in the samples collected from the patients. The sensitivity of the test is $50 \%$ at Days $1-6,91.7 \%$ at Day 7 and after that and its specificity is $97.5 \%$. The duration of the test is $10-15 \mathrm{~min}$ and employing the reader is optional for monitoring the results [68,69]. iChroma COVID-19 Ab is another FIA developed using fluorescent-labelled conjugated. The assay demonstrated no cross-reaction with other respiratory pathogens and reported the results in 10-15 $\mathrm{min}$ with a sensitivity of $95.8-97.0 \%$ [70].

\subsection{Rapid Serological Lateral Flow-Based Tests}

Considering the critical and fatal effects of COVID-19, rapid and accurate diagnostic tests are critical not only for detection of the infection at the earliest stages but to monitor the disease and perform convalescence studies to control any outbreaks [71,72]. Compared with lab-based diagnostic strategies, rapid serological assays have gained much attention since they are applicable in the near-patient or even at home for prompt and simple wide screening and detection of the specific antibodies against the pathogens [73]. However, several intrinsic shortcomings are currently associated with them such as poor clinical accuracy, high dependence on the disease stage and lack of the ability to distinguish the neutralizing antibodies and reporting false results. Although the rapid diagnostic tests require an upgrade to overcome these limitations, they play a fundamental role in diagnostic and epidemiologic studies to be adapted as reliable tools to be employed in the future pandemic.

Almost all of the rapid serological tests for SARS-CoV-2 detection are cassette-based devices relying on LFIAs or so-called Immunochromatographic strip tests (IST). Lateral Flow Assays (LFAs) are paper-based platforms for POC detection of infectious diseases such as COVID-19 as portable, fast, user-friendly and easily operated tests without requiring complex instruments and technical training. Detection using LFAs is based on specific protein-protein interactions using a chromatographic system [31]. One of the advantages of this assay is the ability to implement multiple tests and control bands simultaneously to rapidly detect multiple analytes in a single sample [74]. Qualitative or semi-quantitative rapid serological in vitro diagnostics (IVDs) are significantly cost-effective and deliver the results within 5-30 min. Such devices do not require to be performed by trained laboratory staff and are applicable in hospitals, emergency rooms and other patient care settings [75].

In LFIA strips, the first step is using a colorimetric method to detect the presence of the specific analyte(s). For this aim, biorecognition elements are fixed in the test line(s), and a control line to confirm the validity of the test (Figure 2) [76,77]. LFIA coloured signal reporters or reader-based qualitative and semi-quantitative reporters including carbon material, fluorescent particles, Quantum Dots (QDs), enzyme, liposome, magnetic nanoparticles or other nanoparticles detect the presence of specific antibodies [76]. Qualitative LFIAs achieve more accurate results due to adapting the signal transducer. Various transducers like electrical, optical and magnetic readers are employed in these systems to produce digital signals by transforming the labels of the captured particle [78]. However, these quantitative tests are not able to detect multi targets simultaneously. Moreover, they 
are scanner-based and require expensive instruments for monitoring, which is not suitable for a POC test [79].

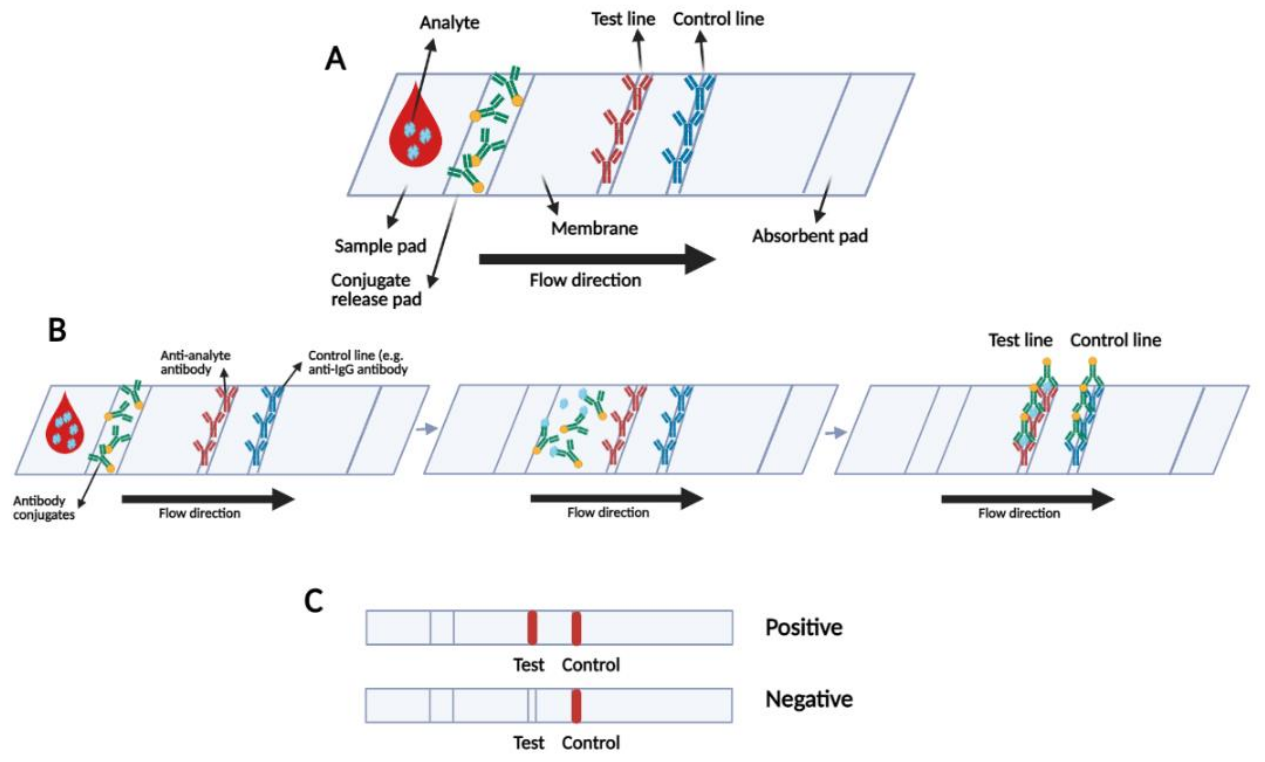

Figure 2. (A) Schematic of LFIA test strip; (B) mechanism of LFIA operation and (C) possible visual positive and negative results.

For POC detection of the infection, the potential monitoring strategy is relying on the colour change visible to the naked eyes. Hence, colloidal gold nanoparticle (AuNP) is usually the preferred reporter which is widely observed in the developed and commercialized rapid tests due to its long-term stability, easy operation, rapid onsite detection, low costs, no requirement for complex and expensive instruments and eye-reading results, being highly biocompatible and negligible biological toxicity. However, AuNP-based LFIAs are not capable of performing quantitative measurements. One other drawback of these strips is the lower sensitivity compared with reader-based reporters [80]. The overall structure and workflow of the LFIA rapid tests for COVID-19 detection are almost similar with some differences such as the type of the reporter, capture molecule(s) and selected target(s) have a crucial impact on the sensitivity and accuracy of the device [81].

Almost all of these tests require a small amount of 10-20 $\mu \mathrm{L}$ of the sample from suspected patients, and the results are reported in about less than 30 min (Table 3) [52]. Cellex qSARS-CoV-2 IgG/IgM Rapid Test, the first FDA EUA approved rapid serological cassette-based test, consists of a burgundy-coloured conjugate pad containing SARS-CoV-2 recombinant $\mathrm{S}$ and $\mathrm{N}$ proteins as antigens conjugated with colloidal gold (SARS-CoV-2 conjugates) and rabbit IgG-gold conjugates. NC membrane strip houses an IgG line (G Line) coated with anti-human IgG, an IgM line (M Line) coated with anti-human IgM and the control line (C Line) coated with goat anti-rabbit IgG [82]. MyBioSource is another company developing SARS-CoV-2 IgM/IgG Antibody Assay Kit targeting total antibodies against the $\mathrm{N}$ protein of SARS-CoV-2 [83]. One of the rapid serological tests with good performance is developed by BioMedomics targeting $\operatorname{IgG} / \operatorname{IgM}$ antibodies with $10 \mu \mathrm{L}$ of serum/plasma or $20 \mu \mathrm{L}$ finger-pricked blood in as low as $10 \mathrm{~min}$ [84]. One other prospective assay is Pharmacy AG SARS-CoV-2 rapid providing the results in 20 min [85]. Panagiota I. Kontou and colleagues evaluated IgG and IgM tests based on ELISA, CLIA, FIA and LFIA in COVID-19 positive samples in a systematic review. The results illustrated that tests using $\mathrm{S}$ antigen are more sensitive than $\mathrm{N}$ antigen-based ones capturing antibodies. It was also demonstrated that IgG tests have better performance and show a better sensitivity when the patients are in the latest days after symptom initiation. However, the combination of both antibodies achieved the best result. ELISA- and CLIA-based tests achieved the best sensitivity of about $90-94 \%$, this value ranged from $80 \%$ to $89 \%$ for LFIA and FIA [26]. 
Table 3. Selected rapid LFIA serological tests for COVID-19 detection and their performance.

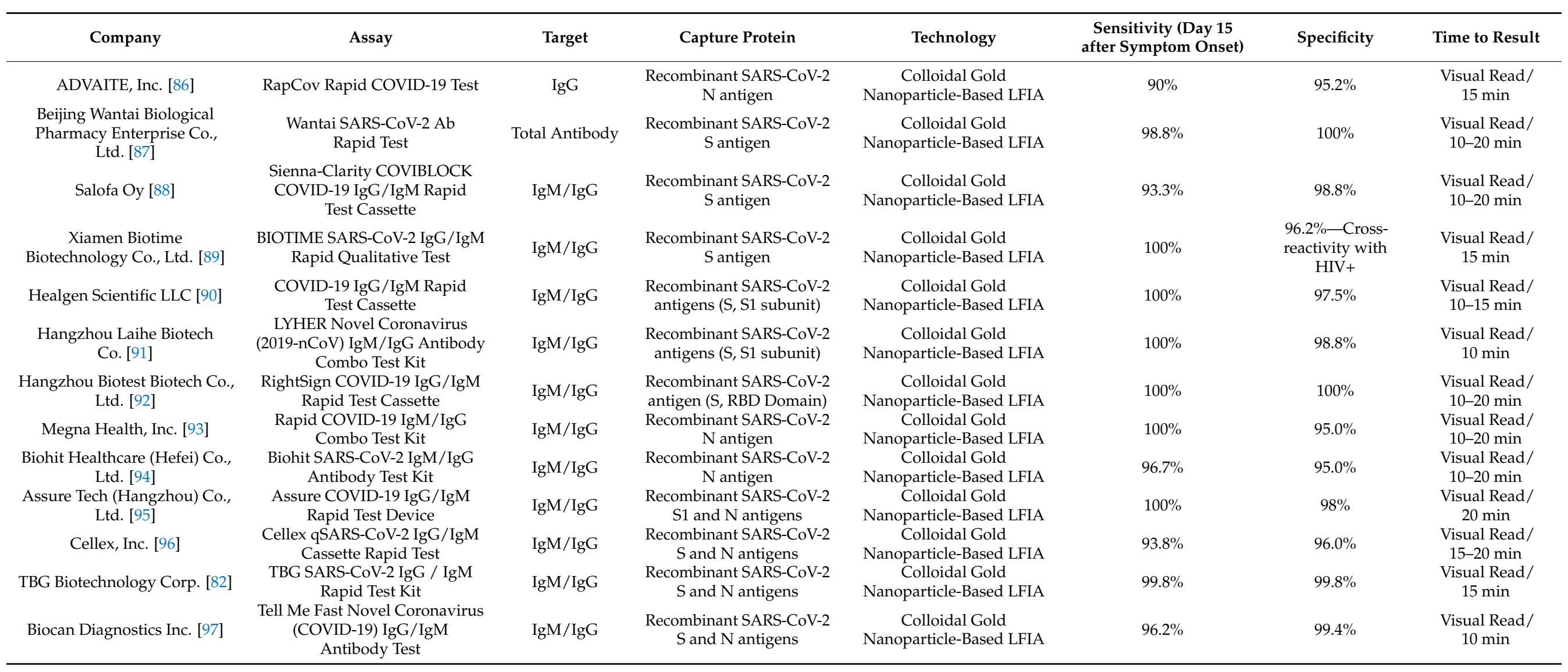


Although reporter nanoparticles in most of the rapid tests are gold, some researchers and companies have developed strips using different detection techniques. The DPP COVID-19 IgM/IgG test introduced by Chembio Diagnostics reporting the results in 15 min requiring optical readout using MicroReader 1 and 2 analyzers [98]. The FDA EUA had revoked the EUA of this test due to the effectiveness for IgM, the sensitivity of 50\% and $93.3 \%$ for $\operatorname{IgM}$ and $\operatorname{IgG}$, respectively [52]. Chen and colleagues are another group that developed a test using LFIA that uses lanthanide-doped polystyrene nanoparticles (LNPs) for anti-SARV-CoV-2 IgG detection in human serum [99].

Until now, rapid strips have been widely adapted for novel coronavirus detection; however, this strategy requires to be modified in the future to be more accurate and reliable. The investigations demonstrate that the accuracy of the LFIA tests is lower compared with qRT-PCR tests. As a critical shortcoming, many reports illustrate that many of the developed LF tests suffer from sensitivity lower than 70\% [100-103]. FDA EUA given to some of the rapid LFIAs are even revoked due to low accuracy and false-negative results such as Autobio Diagnostics Co., Ltd.'s Anti-SARS-CoV-2 Rapid Test and Chembio Diagnostic Systems, Inc.'s DPP COVID-19 IgM/IgG System. Generally, due to their lower sensitivity and a higher rate of cross-reactivity with other respiratory pathogens resulting in false-negative and false-positive results, respectively, rapid LFIA tests are better to be conducted as supplementary tests to confirm RT-PCR results especially when the sample is reported negative [52]. In some cases, rapid LFIAs are comparable with the automated complex CLIA serological assays such as LIAISON SARS-CoV-2 S1/S2 IgG and compete with them due to their low costs and simplicity and similar accuracy.

\subsection{Protein Microarray}

Antibody microarrays, or so-called antigen microarrays, belong to the category of protein microarrays with the unique capabilities and taking advantage of a novel promising proteomic technology performing high throughput, multiplex and miniaturized tests to target low-abundant analytes in the samples [104]. ELISA and LFIA are capable of targeting single or a few proteins; conversely, protein microarrays provide a proteomewide characterization of the present antibodies in response to SARS-CoV-2 antigens [105]. This strategy is preferred for profiling antibodies by enabling antibody screening using some or all of the proteins present in SARS-CoV-2 particles with a high resolution [106]. SARS-CoV-2 genome encodes 28 proteins including 5 structural, 15 nonstructural and 8 accessory proteins; specific polypeptides from these 28 proteins can be employed for the fabrication of SARS-CoV-2 specific arrays [6].

The main limitation of the protein microarrays is the higher turn-around time (TaT) than most of the serological tests and the total duration of this test takes less than $24 \mathrm{~h}$ including sample preparation to data analysis [107]. Since the initiation of the COVID19 pandemic, researchers and manufacturers have developed lab-based microarrays to screen and capture the SARS-CoV-2 specific antibodies. Jiang and colleagues proposed an antibody microarray to profile the SARS-CoV-2 specific IgG/IgM convalescence responses. Firstly, the oligonucleotides related to all of the SARS-CoV-2 proteins including RBD of S1 subunit were obtained from GeneBank, synthesized and cloned in E. coli BL21. Then, a total of 18 proteins including proteins extracted from the sequences of $\mathrm{N}$ gene, $\mathrm{S}$ gene or other ORFs of viral RNA including E gene and nsp genes were spotted on the PATH substrate slide and formed a $2 \times 7$ subarray format. The test was evaluated using 29 serum samples collected from recovered patients, and the results clearly illustrated that S1 and N protein are suitable for detection, $\mathrm{S} 1$ with higher sensitivity than $\mathrm{N}$ protein. The responses of the antibodies to ORF9b and NSP5 proteins were also significant. The data provide insights in the field of vaccine development as well as diagnostics and therapeutics [108]. Wang et al. developed a SARS-CoV-2 proteome microarray by immobilized 15 amino acid-long peptides with 5-amino acid overlap to cover all the proteomes. The processing time is estimated $1.5 \mathrm{~h}$ for this array with an LoD of $94 \mathrm{pg} / \mathrm{mL}$. This peptide-based SARS- 
COV-2 proteome microarray was capable of profiling antibodies and epitopes related to COVID-19 [106].

The developed and commercialized antibodies for CODIV-19 produced by this company and other manufactures along with their main characteristics are presented in Table 4. Quotient Limited company has announced a novel antibody array developed for COVID-19 detection. MosaiQ ${ }^{\mathrm{TM}}$ COVID-19 Antibody Magazine FDA EUA approved a commercialized device to detect IgG and IgM antibodies against the Spike S1 protein secreted in response to SARS-CoV-2. MosaiQ platform allows disease screening of patient blood and produces a comprehensive result in about $35 \mathrm{~min}$. The inputs for this array are anticoagulated blood samples centrifuged and loaded with the throughput of 3000 tests in $24 \mathrm{~h}$. With the presence of SARS-CoV-2 specific IgG and IgM antibodies, they will bind to the appropriate probes and the positive results are visualized and interpreted by the instrument camera as black spots for COVID-19 samples. Each microarray generates a reaction on 132 printed biological markers. The required sample volume is as low as $5 \mu \mathrm{L}$ for each test and, after reporting the first result, the other results will be available every $24 \mathrm{~s}[109,110]$. The performance of this microarray for the detection of COVID-19 specific antibodies has recently been evaluated using serum samples from Blood Donation Screening Laboratory and demonstrated high clinical accuracy; before the day from symptom onset, the sensitivity of IgG detection was $71-80 \%$, while this rate was increased to about $100 \%$ after day 15 which was superior to some other high-throughput available antibody assays such as EuroImmun (sensitivity: 71\%), Abbott (overall sensitivity: 78\%) or Roche (overall sensitivity: $76 \%$ ). The specificity of the MosaiQ ${ }^{\circledR}$ test was also evaluated $100 \%$ and higher than the three other well-known tests $[111,112]$. This chemiluminescence-based kit is one of the most expensive and complex automated COVID-19 detecting technologies while offering the throughput of thousands of samples per day with a short duration of the test. The fact is that such complex and expensive technologies have demonstrated comparable accuracies with simple and low-cost tests which require no trained laboratory personnel. For the tests with comparable sensitivity and specificity, the rapid tests with a simple workflow and lower cost compete with the complex and costly tests requiring trained laboratory staff [113].

Sinommune ${ }^{\mathrm{TM}}$ Antigen Multiplex Microarray is another serosurveillance array developed collaboratively by Sino Biological and Nanoimmune Inc. for COVID-19 detection. This microarray consists of nitrocellulose slides containing single array pads with hundreds of spots including pre-printed recombinant antigens which are absorbed onto the 3D nc slide. This array includes 65 viral antigens including S1, S2, S1 + S2, HE, N, S RBD and Plpro antigens specific for SARS-CoV-2 and other selected five groups of coronavirus family for investigating their reaction with SARS-CoV-2 specific IgG antibody [120]. ImmuSAFE ${ }^{\mathrm{TM}}$ is another company that has developed a patented technology to develop three different antibody microarrays using multiple domains, full-length and numerous truncated versions of SARS-CoV-2 $\mathrm{S}$ and $\mathrm{N}$ proteins. The chip determines different IgG, IgA, IgM antibodies and IgG1-4 subclasses. ImmuSAFE ${ }^{\mathrm{TM}}$ are also capable of assessing the response of the patient to the vaccines by differentiating the antibodies secreted in response to the vaccine, or they are a result of a previous infection [118]. 
Table 4. The developed protein microarray-based tests for COVID-19 detection.

\begin{tabular}{|c|c|c|c|c|c|c|c|c|}
\hline Manufacturer & Test & Target & Microarray Content & Sensitivity & Specificity & Format & Regulatory Status & Note \\
\hline $\begin{array}{l}\text { Quotient Limited } \\
\text { SAÂ [29] }\end{array}$ & $\begin{array}{l}\text { MosaiQ }{ }^{\mathrm{TM}} \\
\text { COVID-19 Antibody } \\
\text { Microarray }\end{array}$ & $\begin{array}{l}\text { IgG, IgM directed } \\
\text { to SARS-CoV-2 } \\
\text { S protein }\end{array}$ & $\begin{array}{l}\text { SARS-CoV-2 S } \\
\text { protein antigens }\end{array}$ & $\begin{array}{l}\text { Varies based on the } \\
\text { phase of the disease } \\
(71-100 \%)\end{array}$ & $99.8 \%$ & $\begin{array}{l}\text { High-throughput automated } \\
\text { Immunoassay-Antibody } \\
\text { employing enhancement } \\
\text { reagent to enable silver to } \\
\text { nucleate on the } \\
\text { gold nanoparticles }\end{array}$ & FDA EUA-CE-IVD & $\begin{array}{l}35 \text { min for the first } \\
\text { microarray, } 24 \mathrm{~s} \text { for each } \\
\text { next microarray. }\end{array}$ \\
\hline $\begin{array}{l}\text { PEPperPRINT } \\
\text { GmbH [114] }\end{array}$ & $\begin{array}{l}\text { PEPperCHIP } \\
\text { SARS-CoV-2 } \\
\text { Proteome } \\
\text { Microarray }\end{array}$ & $\operatorname{IgG}, \operatorname{Ig} \mathrm{A}$, and $\operatorname{IgM}$ & $\begin{array}{l}\text { The whole proteome of } \\
\text { SARS-CoV-2 (GenBank } \\
\text { ID: MN908947.3) } \\
\text { translated into } \\
\text { overlapping peptides }\end{array}$ & (No info) & (No info) & $\begin{array}{l}\text { Manual-One single } \\
\text { peptide array }\end{array}$ & CE-IVD & $\begin{array}{l}\text { For vaccine development, } \\
\text { or screen viral antigens } \\
\text { to find and characterize } \\
\text { immunodominant } \\
\text { epitopes for in-vitro } \\
\text { diagnostics research }\end{array}$ \\
\hline $\begin{array}{l}\text { PEPperPRINT } \\
\text { GmbH [115] }\end{array}$ & $\begin{array}{l}\text { PEPperCHIP }{ }^{\circledR} \\
\text { SARS-CoV Antigen } \\
\text { Microarray }\end{array}$ & $\begin{array}{l}\text { SARS-CoV-2 } \\
\text { specific Antibodies }\end{array}$ & $\mathrm{S}, \mathrm{N}, \mathrm{M}$ and $\mathrm{E}$ antigens & (No info) & $\begin{array}{l}\text { no cross- } \\
\text { reactivity }\end{array}$ & $\begin{array}{l}\text { Manual- Containing three } \\
\text { array copies per microarray, } \\
\text { with } 998 \text { antigen specific } \\
\text { peptides printed in duplicate }\end{array}$ & CE-IVD & $\begin{array}{l}\text { including a two-day } \\
\text { experimental workflow }\end{array}$ \\
\hline $\begin{array}{l}\text { PEPperPRINT } \\
\text { GmbH [116] }\end{array}$ & $\begin{array}{l}\text { PEPperCHIP }{ }^{\circledR} \\
\text { Pan-Corona Spike } \\
\text { Protein Microarray }\end{array}$ & $\begin{array}{l}\text { Antibodies against } \\
\mathrm{S} \text { antigen }\end{array}$ & $\begin{array}{l}\text { S proteins derived } \\
\text { from seven } \\
\text { coronaviruses } \\
\text { translated into } \\
\text { overlapping peptides }\end{array}$ & (No info) & (No info) & $\begin{array}{l}\text { One array with } 4564 \text { peptides } \\
\text { in duplicate }\end{array}$ & RUO & $\begin{array}{l}\text { For Serum antibody } \\
\text { fingerprint analysis, } \\
\text { Immune monitoring and } \\
\text { Epitope studies }\end{array}$ \\
\hline $\begin{array}{l}\text { Sengenics } \\
\text { Corporation Pte } \\
\text { Ltd. [118] }\end{array}$ & $\begin{array}{l}\text { ImmuSAFETM } \\
\text { Respiratory Virus } \\
\text { Protein Microarray }\end{array}$ & $\begin{array}{l}\text { SARS-CoV-2 } \\
\text { specific Antibodies }\end{array}$ & $\begin{array}{l}\text { Multiple SARS-CoV-2 } \\
\text { proteins, } \mathrm{N} \text { from } 5 \\
\text { other human } \\
\text { Coronaviruses as well } \\
\text { as Influenza A and B } \\
\text { HA antigen subtypes }\end{array}$ & (No info) & (No info) & $\begin{array}{l}\text { Manual or automated single } \\
\text { and double-colour } \\
\text { fluorescently-labelled } \\
\text { antibody assay }\end{array}$ & RUO & $\begin{array}{l}\text { The key application is for } \\
\text { research and } \\
\text { development purposes }\end{array}$ \\
\hline $\begin{array}{l}\text { Sengenics } \\
\text { Corporation Pte } \\
\text { Ltd. [119] }\end{array}$ & $\begin{array}{l}\text { ImmuSAFE }^{\mathrm{TM}} \\
\text { COVID+ } \\
\text { Biochip Test }\end{array}$ & $\begin{array}{l}\text { SARS-CoV-2 } \\
\text { specific Antibodies }\end{array}$ & $\begin{array}{l}\text { Multiple SARS-CoV-2 } \\
\text { specific domains (N } \\
\text { and S) including } \\
\text { full-length and } \\
\text { numerous } \\
\text { truncated versions }\end{array}$ & (No info) & (No info) & $\begin{array}{l}\text { Single-colour } \\
\text { fluorescently-labelled } \\
\text { antibody assay, and } \\
\text { Dual-colour } \\
\text { fluorescently-labelled } \\
\text { antibody assays for } \\
\text { quantitative analysis }\end{array}$ & RUO & $\begin{array}{l}24 \text { arrays per slide } \\
\text { (24 samples per } \\
\text { slide)-Key applications } \\
\text { are vaccine clinical trials } \\
\text { and seroprevalence } \\
\text { research studies. }\end{array}$ \\
\hline
\end{tabular}




\section{Rapid Antigenic Tests}

Antigenic assays are the second category of protein-based tests which are newly released to the market. This strategy relies on capturing the specific virus antigens in a mixture using an antibody-antigen attachment to detect the presence of the viral particles directly [121]. Currently, LFIA is the preferred technology for the development of rapid POC and at-home antigenic tools. The antigenic tests are the only tools that have been received to be used at home even without a prescription or requiring assistance from a specialist [122].

The clinical performance of these tools is hugely dependent on various factors and the patient's situation. The best time window for sensing the viral particles is the first week after the infection. The viral load is elevated at this time and antigen tests demonstrate their best performance. This amount decreases during the time which results in dropping the accuracy of the antigen testing in the next stages of the disease [123]. Another factor is the sample type which could directly affect the test results. Most of the current antigendetecting tests are based on nasopharyngeal specimens which is similar to the gold standard RT-PCR tests and the measurement of the accuracy is less complicated [124]. However, the rest of the kits test nasal samples with a few ones detecting the antigens in salivary specimens. The variation in the sample type increases the complexity of the evaluating procedure using the gold standard which recommends using nasopharyngeal swabs [125].

The most frequently present protein in SARS-CoV-2 structure is the $\mathrm{N}$ protein, an evolutionary conserved and highly immunogenic phosphoprotein. $S$ protein, specifically in the S1 RBD subdomain, is another immunogenic protein on the viral particle surface with rare changes in the amino acids. All of the antigen detecting tests apply antibodies specific to SARS-CoV-2 proteins, more frequently $\mathrm{N}$ antigen, as capture molecules. Rapid antigen tests have some advantages over PCR such as lower costs and faster speed. They are highly specific for SARS-CoV-2 but demonstrate a low sensitivity; this is one of the main current limitations of the antigenic tests explaining why they may not detect all of the active coronaviruses [126].

As of 15 February 2021, the number of the developed antigenic tests have been far less than the serological tests (Table 5) [52]. A portion of the developed antigenic tests employ Colloidal Gold Nanoparticles (AuNPs) as the reporter for visual detection of the infection. Conversely, the rest of these kits require a specific instrument for the detection step. Although the visual detection is simpler and cost-effective requiring less equipment, the reader-based tests have the advantage of getting the results automatically from the analyzer and releasing the results sending messages and posting the results to the patient file by integrating Laboratory Information System (LIS) to their detecting system [127].

On May 8, FDA authorized the first antigenic test developed by Quidel Corporation, Sofia SARS Antigen FIA to perform tests in authorized laboratories and also POC settings. This test is a cassette-based LF immunofluorescent sandwich assay that detects viral $\mathrm{N}$ protein. Sofia2 or Sofia analyzer is required for qualitative detection. The results are reported in $15 \mathrm{~min}$ with $87.5 \%$ sensitivity. The test detects both SARS-CoV and SARS-CoV-2 but is not capable of differentiating them from each other [128]. Sofia 2 Flu + SARS Antigen FIA is an automated test reporting the results of influenza A, influenza B and COVID-19 in a POC setting in $15 \mathrm{~min}$. This sandwich immunofluorescent test should be performed using Sofia 2 instrument and is capable of detecting $\mathrm{N}$ antigens from other pathogens in direct swab specimens. However, the test does not distinguish SARS-CoV-2 from SARS-CoV infected samples [129]. The third FDA EUA authorized antigenic test is a BD Veritor System for Rapid Detection of SARS-CoV-2 developed by Becton, Dickinson and Company (BD). This test employs chromatographic digital immunoassay and detects viral $\mathrm{N}$ protein in the samples taken from the patients in the first five days of symptom initiation. The assay monitoring is not visual and depends on the reader. This test is a rapid (approximately $15 \mathrm{~min}$ ) chromatographic digital immunoassay for the direct and qualitative detection of SARS-CoV-2 antigens in nasal swabs. The sensitivity of this test is $84 \%$ and has a $100 \%$ specificity for COVID-19 detection [130,131]. 
Table 5. A list of the developed Antigen-based tests for COVID-19 detection.

\begin{tabular}{|c|c|c|c|c|c|c|c|}
\hline Manufacturer Name & Test Name & Technology & Target Antigen & $\begin{array}{c}\text { Sensitivity in } \\
\text { Symptomatic Patients }\end{array}$ & Specificity & Detection & Test Duration \\
\hline $\begin{array}{l}\text { Abbott Diagnostics } \\
\text { Scarborough, Inc. [132] }\end{array}$ & $\begin{array}{c}\text { BinaxNOW COVID-19 Ag } \\
\text { Card Home Test }\end{array}$ & $\begin{array}{c}\text { Colloidal Gold } \\
\text { Nanoparticle-Based LFIA, } \\
\text { Prescription Home Testing }\end{array}$ & $\mathrm{N}$ antigen & $97.1 \%$ & $98.5 \%$ & $\begin{array}{c}\text { Visual read + } \\
\text { submitting the result } \\
\text { via the NAVICA mobile } \\
\text { application }\end{array}$ & $15 \mathrm{~min}$ \\
\hline Ellume Limited [133] & $\begin{array}{c}\text { Ellume COVID-19 Home } \\
\text { Test }\end{array}$ & $\begin{array}{l}\text { Fluorescent LF, Over the } \\
\text { Counter (OTC) Home Testing, } \\
\text { Screening }\end{array}$ & $\mathrm{N}$ antigen & $95 \%$ & $97 \%$ & $\begin{array}{l}\text { Instrument Read } \\
\text { (smartphone-based) }\end{array}$ & $15 \mathrm{~min}$ \\
\hline Access Bio, Inc. [134] & $\begin{array}{c}\text { CareStart COVID-19 } \\
\text { Antigen test }\end{array}$ & $\begin{array}{c}\text { Colloidal Gold } \\
\text { Nanoparticle-Based LFIA }\end{array}$ & $\mathrm{N}$ antigen & $88 \%$ & $100 \%$ & Visual read & $10 \mathrm{~min}$ \\
\hline $\begin{array}{l}\text { Princeton BioMeditech } \\
\text { Corp [135] }\end{array}$ & Status COVID-19/Flu & $\begin{array}{l}\text { Colloidal Gold } \\
\text { Nanoparticle-Based LFIA, } \\
\text { Multi-analyte }\end{array}$ & $\mathrm{N}$ antigen & $\begin{aligned} & 93.9 \%(\mathrm{LoD}: \\
2.7 \times & 103 \text { TCID50/mL) }\end{aligned}$ & $93.9 \%$ & Visual Read & $15 \mathrm{~min}$ \\
\hline Celltrion USA, Inc. [136] & COVID-19 Antigen MIA & $\begin{array}{l}\text { Magnetic Force-assisted } \\
\text { Electrochemical Sandwich } \\
\text { Immunoassay (MESIA) } \\
\text { High throughput }\end{array}$ & $\begin{array}{c}\text { S antigen } \\
\text { (RBD domain) }\end{array}$ & $\begin{array}{c}\text { 94.4\% (LoD: } \\
3.0 \times 101 \text { TCID50/mL) }\end{array}$ & $100 \%$ & Instrument Read & $10 \mathrm{~min}$ \\
\hline Quanterix Corporation [137] & $\begin{array}{c}\text { Simoa SARS-CoV-2 N } \\
\text { Protein Antigen Test }\end{array}$ & $\begin{array}{l}\text { Paramagnetic } \\
\text { Microbead-based } \\
\text { Immunoassay }\end{array}$ & $\mathrm{N}$ antigen & $\begin{array}{c}97.70 \%(\mathrm{LoD}: \\
0.31 \text { TCID50/mL) }\end{array}$ & $\begin{array}{l}\text { Cross-reaction with } \\
\text { SARS-CoV }\end{array}$ & Instrument Read & $80 \mathrm{~min}$ \\
\hline Luminostics, Inc. [138] & $\begin{array}{l}\text { Clip COVID Rapid } \\
\text { Antigen Test }\end{array}$ & LF immunoluminescent assay & $\mathrm{N}$ antigen & $\begin{array}{c}(\text { LoD: } \\
0.88 \times 102 \text { TCID50/mL) }\end{array}$ & $\begin{array}{l}\text { Cross-reaction with } \\
\text { SARS-CoV }\end{array}$ & $\begin{array}{l}\text { Instrument Read } \\
\text { (smartphone-based) } \\
\text { Visual Read }+\end{array}$ & $30 \mathrm{~min}$ \\
\hline $\begin{array}{l}\text { Abbott Diagnostics } \\
\text { Scarborough, Inc. [139] }\end{array}$ & $\begin{array}{c}\text { BinaxNOW COVID-19 } \\
\text { Ag Card }\end{array}$ & $\begin{array}{c}\text { Colloidal Gold } \\
\text { Nanoparticle-Based LFIA }\end{array}$ & $\mathrm{N}$ antigen & $97.1 \% / 22.5$ TCID50/mL & $98.5 \%$ & $\begin{array}{l}\text { submitting the result } \\
\text { via the NAVICA } \\
\text { mobile application }\end{array}$ & $15 \mathrm{~min}$ \\
\hline LumiraDx UK Ltd. [140] & $\begin{array}{c}\text { LumiraDx SARS-CoV-2 } \\
\text { Ag Test }\end{array}$ & FIA & $\mathrm{N}$ antigen & 97.6\% /32 TCID50/mL & $96.6 \%$ & Instrument Read & $12 \mathrm{~min}$ \\
\hline $\begin{array}{l}\text { Becton, Dickinson and } \\
\text { Company (BD) [131] }\end{array}$ & $\begin{array}{l}\text { BD Veritor System for Rapid } \\
\text { Detection of SARS-CoV-2 }\end{array}$ & $\begin{array}{c}\text { Chromatographic digital } \\
\text { immunoassay }\end{array}$ & $\mathrm{N}$ antigen & $84 \%$ & No cross-reaction & Instrument Read & $15 \mathrm{~min}$ \\
\hline Quidel Corporation [128] & Sofia SARS Antigen FIA & FIA & $\mathrm{N}$ antigen & $87.5 \%$ & $\begin{array}{l}\text { Cross-reaction with } \\
\text { SARS-CoV }\end{array}$ & Instrument Read & $15 \mathrm{~min}$ \\
\hline Quidel Corporation [141] & $\begin{array}{c}\text { Sofia } 2 \text { Flu + SARS } \\
\text { Antigen FIA }\end{array}$ & FIA & $\mathrm{N}$ antigen & (No info) & $\begin{array}{l}\text { Cross-reaction with } \\
\text { SARS-CoV }\end{array}$ & Instrument Read & $15 \mathrm{~min}$ \\
\hline
\end{tabular}


Lin et al. have developed a POC microfluidic immunoassay for detection of IgG/IgM/ SARS-CoV-2 Antigen simultaneously in $15 \mathrm{~min}$ and evaluated its clinical performance using 28 healthy and 26 COVID-19 samples (Figure 3). They combined various biomarkers as targets to increase the accuracy of the assay. This sample-to-answer test requires $10 \mu \mathrm{L}$ and $70 \mu \mathrm{L}$ dilution buffer as indicated. While the sample is COVID-19 positive, SARSCoV-2 biomarkers attach to the capture antibodies which are coated with FMS (fluorescent microsphere) and the formed complex is immobilized on the fluorescence test region via a second interaction due to antigen-antibody interaction. After a 10-min duration, the portable fluorescence analyzer reports the results. The achieved cut-off was 100 (T value) for antigen detection, and 200 for sensing each $\operatorname{IgG}$ and IgM antibody. It was also observed that serum samples have a significantly fluorescent value compared with a pharyngeal swab. The proposed assay was then tested with samples from patients in 1-7 days onset and over 14 days after symptom separately which demonstrated a growth in the $T$ value while the time changed [142].
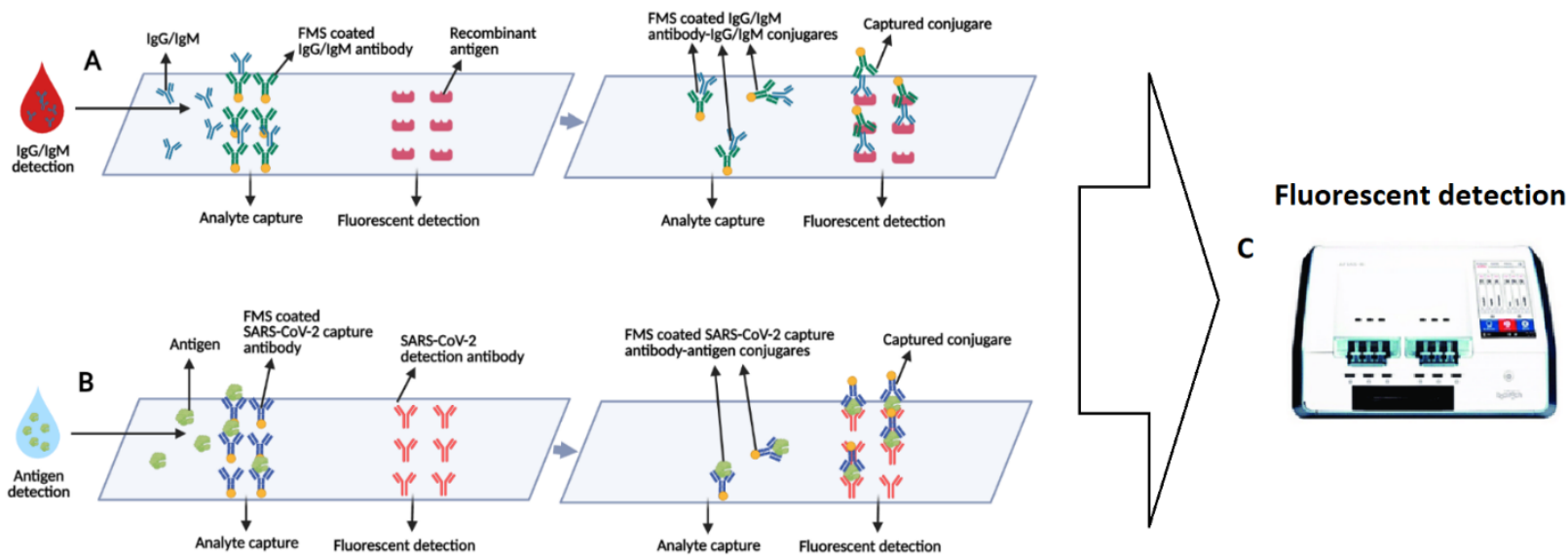

Figure 3. Schematic of the microfluidic fluorescence immunoassay for simultaneous detection of the antibodies and antigens. (A) Schematics of IgG/IgM detection and (B) schematics of antigen detection of SARS-CoV-2 using microfluidic FIA. (C) The results of both of the tests are simultaneously reported by using a portable fluorescence detecting device.

LumiraDx SARS-CoV-2 Ag Test takes advantage of microfluidic FIA, antibodies specific to SARS-CoV-2 N protein are applied in the FIA and target viral $\mathrm{N}$ antigen in the collected specimens. The test has demonstrated no cross-reaction with other respiratory pathogens such as SARS-CoV-2 and reports the results in $12 \mathrm{~min}$ as one of the fastest antigenic tests. However, like the BD Veritor System, the LumiraDx SARS-CoV-2 Ag Test does not present visual results and requires to be monitored using the LumiraDx Instrument. The sensitivity and specificity of the test are measured $97.6 \%$ and $96.6 \%$ with an LoD of 32 TCID50/mL [143]. BinaxNOW COVID-19 Ag Card developed by Abbott Diagnostics is an LFIA targeting virus $\mathrm{N}$ protein with high sensitivity of $97.1 \%$ and low LoD of $22.5 \mathrm{TCID} 50 / \mathrm{mL}$. The obtained results can be uploaded in NAVICA, a smartphone application developed by Abbott company. By uploading the COVID-19 negative results to this application, NAVICA-enabled organizations such as banks or workplaces will easily have access to the COVID-19 status of the people [144,145].

PCL Inc. has also introduced the new PCL COVID19 Ag Rapid FIA test. This test has received a certificate from different regulators including CE-IVD. This device is a POC rapid and cassette-based fluorescent immunoassay targeting SARS-CoV-2 N protein as an antigen is oropharyngeal, nasopharyngeal and sputum samples. The results are achieved in as fast as $10 \mathrm{~min}$ and FLA Analyzer is used as a fluorescent reader. Based on the manufacturing, the LoD of the test is $1000 \mathrm{PFU}$ (active viruses), and its sensitivity and specificity are $100 \%$ and $97.78 \%$, respectively [146]. Another research group has targeted the SARS-CoV-2 protein via Field-Effect Transistor-Based Biosensor using a specific IgG antibody against the SARS-CoV-2 spike protein [147]. 
The Simoa SARS-CoV-2 N Protein Antigen Test has recently been given FDA EUA for COVID-19 detection. Among all of the approved antigen tests, this test is the only high throughput kit with a higher TaT of about $80 \mathrm{~min}$, although results are reported in 150 min for 96 tests. This test is a Paramagnetic Microbead-based Immunoassay requiring an analyzer for interpretation but does not differentiate SARS-CoV-2 and SARS-CoV from each other in the infected specimens [148]. The Clip COVID Rapid Antigen Test is the other authorized tool that is developed in a smartphone-based setting for the interpretation and measurement of the luminescence signal emitted from the luminescent nanomaterials [131].

An important application of the rapid diagnostic tools is at home and near-patient testing. Fortunately, two rapid antigenic tests have recently been given FDA EUA to be applied as home tests with or without prescription, [52]. The Ellume COVID-19 Home Test respectively is the first FDA EUA authorized non-prescription fully at-home COVID-19 detecting test that can be completely performed at home with the patient to detect or follow up on the infection. This test employs fluorescent LFIA for the detection of $\mathrm{N}$ antigen of SARS-CoV-2 and requires a smartphone as the readout instrument to report the results [149]. The Clip COVID Rapid Antigen Test is another FDA EUA approved tool for at-home testing which requires a prescription. Interestingly, the PPA and NPA of the Ellume COVID-19 Home Test are obtained 91\% and 96\%, respectively, for the asymptomatic cases, and $96 \%$ and $100 \%$, respectively, for the symptomatic individuals which are very promising [136]. With such at-home tests, the self-isolation of the infected people and the disease follow up take place in a limited area minimizing the viral spread and assistance of the medical care system which not only significantly reduces the rate of the infection in the community but also provides critical information regarding the immune system during the quarantine days.

\section{Other Biosensors}

Considering the increasing demand for rapid, cost-effective and accurate tests for COVID-19 detection, a wide range of technologies have been developed to overcome the shortages in the testing area [150]. Researchers have recently reported a variety of biosensing strategies such as electrochemical, optical, electrical, mechanical and piezoelectric biosensors for the detection of pathogens. Among various biosensing technologies, field effective transistors have attracted scientists' attention due to the miniaturized size, fast and sensitive response and parallel sensing with the potential of being used in the POC setting [151]. Seo and colleagues have introduced a graphene-based FET-based biosensor for SARS-CoV-2 rapid detection [147]. A 2D graphene sheet has the advantage of high carrier mobility and electrode conductivity as well as large specific areas that make it a reliable material for sensing purposes [152]. In this COVID-19 FET sensor, the sensitive graphene layer on the device is coated with a commercially available IgG antibody against the SARS-CoV-2 S spike protein. The performance of IgG antibodies was first validated using ELISA and then they were used as a receptor for SARS-CoV-2 detection. The immobilization of the IgG antibodies was completed using a probe linker, 1-pyrenebutyric acid N-hydroxysuccinimide ester (PBASE), which is an efficient agent for interface coupling. The fabricated device observed a real-time response and successfully detected SARS-CoV-2 $\mathrm{S}$ in both cultured SARS-CoV-2 virus and transport medium used for nasopharyngeal swabs antigens with high sensitivity and LoD of $1 \mathrm{fg} / \mathrm{mL}$ with the ability to differentiate it from MERS-CoV [147]. Apart from the considerable sensitivity and low LoD, the measuring set-up requires a costly and low-throughput semiconductor analyzer; in addition, a high concentration of the antibody $(250 \mu \mathrm{g} / \mathrm{mL})$ is needed for the functionalization of the device.

COVID-19 has also been detected using field-deployable/portable plasmonic fibreoptic absorbance biosensors (P-FAB). This device is developed based on P-FAB with the LoD of detecting down to attomolar (10-18 M) protein concentrations. P-FAB technology monitors the changes in the intensity/absorbent or power loss in the light which is propagated in a multimode U-bent fibre-optic probe using a green LED and a photode- 
tector. Two assays have been suggested for this aim, one using a labelled approach and another one is label-free. In the former, AuNPs are immobilized on the biosensor and then covalently conjugated with anti-N protein monoclonal antibodies (detector antibody) by thiol-PEG-NHS binding. Non-specific interactions are prevented by bovine serum albumin (BSA) treatment. These biofunctionalized probes will detect $\mathrm{N}$ protein of the SARS-CoV-2 in saliva samples in $15 \mathrm{~min}$. On the other hand, the latter employs AuNP-labeled capture and detector antibodies in a sandwich immunoassay. The biosensor matrix is first coated with anti-N protein monoclonal antibodies on the U-bent fibre-optic probe and then treated with BSA. The sample should be mixed with anti-N protein antibodies-gold nanoparticles' conjugates and introduced to the sensing area. The results will be achieved in $5 \mathrm{~min}$. Among these two introduced technologies, the label-free assay is more promising due to its one-step response with no need for reagents, but its drawback is poor specificity. In general, the sensitivity and low LoD of the devices over LFAs are considerable, and P-FAB technology has the potential to be developed as a COVID-19 diagnostic test to fight the pandemic [153].

Bioelectric recognition assay has been used in the development of a novel rapid and portable cell-based biosensor for COVID-19 detection. This method is based on Molecular Identification through Membrane Engineering, in which human chimeric spike S1-RBD specific antibody, recombinant human IgG1, was inserted into mammalian Vero cells via electroinserting. By the presence of viral $S$ proteins is positive samples, they attach to their specific antibody on the surface of the cells and make a unique difference in biorecognition elements' electric properties. This hyperpolarization was measured and recorded by a cell-biosensor, a customized multichannel potentiometer with a polydimethylsiloxane (PDMS) layer containing eight holes on its electrode's polyester part. After the application, for the readout section, the potentiometer was connected to a tablet and recorded the measurements. The test did not require any sample-preparation steps, and the LoD of the test was $1 \mathrm{fg} / \mathrm{mL}$ and showed no cross-reaction with SARS-CoV-2 N protein. The range of responses was semi-linear from $10 \mathrm{fg}$ to $1 \mu \mathrm{g} / \mathrm{mL}$ [154].

PathSensors Inc. is another company developing its sensor, CANARY biosensor, for novel coronavirus detection using a cell-based technology in $5 \mathrm{~min}$. The test is based on CANARY TM technology. In summary, the test is made by genetically engineering $B$ lymphocytes with bioluminescence from jellyfish and specific antibodies developed in mice. The engineered cells are designed to emit light when they are exposed and attached to a secondary pathogen [155]. When SARS-CoV-2 is present, it binds to the specific antibodies on the surface of the engineered cells, and the biosensors detect the viruses and report their presence by emitting light. The presence of the target pathogen is confirmed by measuring light output from the cell [156].

Convat project is one of the funded projects by the H2020 European Union Framework program with the main goal of developing a POC nanophotonic sensor based on silicon photonics interferometric technology and microfluidics lab-on-chip integration. For this aim, three distinct assays are in development, the first one for viral genomic analysis and two others for direct virus detection and serological testing. For direct detection of the virus, SARS-CoV-2 specific monoclonal antibodies and nanobodies are produced, linked to the chip for capturing the complete virus and evaluated using deactivated SARS-CoV-2 virus and real samples from COVID-19 positive patients. The test quantifies the viral load in the sample. For direct RNA detection, WHO recommended sequences for SARSCoV-2 PCR detection were evaluated and three highly specific candidate sequences were selected as targets with a similarity of $100 \%$ to SARS-CoV-2 and $0 \%$ to other genomes (E, $\mathrm{N} 1$ and N gene) with no need for PCR amplification. Different complementary probes are immobilized on the chip to hybridize with the target viral-specific sequences. The device is evaluated with synthetic RNA targets, viral SARS-CoV-2 RNA and RNA of other coronaviruses and the target sequence in the E gene and $\mathrm{N} 1$ gene have an LoD of $1 \mathrm{nM}$ and $3 \mathrm{nM}$, respectively. Direct virus detection takes place by immobilizing anti-S1 antibodies on the surface of the chip and evaluating of its affinity and specificity. The LoD is measured 
at $19 \mathrm{ng} / \mathrm{mL}$ for this test. For the serological test, the targets are viral $\mathrm{N}, \mathrm{S} 1$ and RBD antigens, and the intact virus is detected. The device is evaluated using S serum samples and COVID-19 positive samples. The LoD value of this chip is equal to $446 \mathrm{FFU} / \mathrm{mL}$. The tests are performed in $30 \mathrm{~min}$ [157].

Förster or fluorescence resonance energy transfer (FRET) is another method achieving high resolutions of detection in the range of 1-10 $\mathrm{nm}$ compared with optical techniques. Through FRET signals, protein-protein interactions, protein conformation changes and proteolytic cleaves can be studied even in living cells. For viral protein detection, FRET is capable of sensing protein-protein interactions such as antibody-antigen [158]. FRET technology relies on the energy transfer between a pair of donors and acceptor molecules in a distance-dependent manner. The interaction between two fluorescent-labelled proteins emitting specific colours while distancing, with an overlap in fluorescence emission spectrums, produces a novel third fluorescent colour that differs from the two initial emissions [159]. A useful technology for SARS-CoV-2 study and detection can be FRET-based biosensors. For this aim, viral proteins such as $S$ can be fused to FRET pair-proteins. It also can be utilized to investigate the enzymatic reactions in human cells during COVID-19 infection [160]. SPR-based optical biosensors are other tools which have previously been developed for SARS-CoV detection and can be considered as the other potential tools to be developed for the accurate detection of the SARS-CoV-2 [161].

\section{Discussion}

In this review, we discussed the current and potential protein-based strategies which are developed for COVID-19 detection and have the potential to be adapted for the detection of other pathogens in future pandemics. Having many unsuspected asymptomatic COVID-19 carriers interacting with other people in the society increases the risk of infecting healthy people and makes the virus spread much more quickly. This situation may lead to problems such as overloaded clinics and hospitals. This fact has raised concern regarding not only new coronavirus but also to avoid such probable outbreaks in the future. Early detection and isolation of the positive cases is pivotal for controlling any outbreak. For this aim, the development of rapid and adaptable diagnostic tools plays a critical role to limit the spread of the virus in the earliest stages in the future to avoid such pandemics. Although vaccination has the potential of improving the immune state of our bodies, the challenge is that, after the initiation of each outbreak, at least a few months are required to develop a safe and effective vaccine and large-scale vaccination itself required a long time. More importantly, natural mutations in virus RNA may immunize the virus against the vaccine. For these reasons, mass production of sensitive and low-cost POC diagnostic tools is critical to saving thousands of lives during the first months of the upcoming outbreaks.

Although a large number of the COVID-19 tests have been developed over the last year, it is still difficult to recommend the advantage of each technology over the other ones due to the lack of sufficient clinical reports for most of these tests. However, the main goal of this review is to open the discussion and stimulate the questions for the Bioengineering community and also the designers who are interested in developing and contributing in the diagnostic technologies. For this reason, in each section, we have provided the performance, advantages and disadvantages of each strategy, and we hope this review opens new discussions in the development of the novel assays such as combining the current technologies with electronic biosensors or developing fully integrated devices. As an illustration, in the future, we expect to see the fully integrated lower-cost technologies adoptable for the detection of pathogens in the early stages of the spread to avoid any pandemics. Generally, the protein-based tests have been demonstrated to be very useful during the previous SARS and MERS pandemics, and, in the meantime, they are widely employed for COVID-19 diagnostics as attractive strategies especially for large-scale screening purposes. In conclusion, novel, reliable, accurate, prompt and adaptable protein-based strategies are urgently needed to assist us in the current pandemic and future hazards. 
Author Contributions: Conceptualization, E.G.-Z. and T.S.; methodology, E.G.-Z. and T.S.; software, T.S.; validation, E.G.-Z. and T.S.; formal analysis, E.G.-Z. and T.S.; investigation, E.G.-Z. and T.S.; resources, E.G.-Z. and T.S.; data curation, T.S.; writing-original draft preparation, T.S.; writing review and editing, E.G.-Z. and T.S.; visualization, E.G.-Z. and T.S.; supervision, E.G.-Z.; project administration, E.G.-Z. All authors have read and agreed to the published version of the manuscript.

Funding: This research received no external funding.

Institutional Review Board Statement: Not applicable.

Informed Consent Statement: Not applicable.

Data Availability Statement: Not applicable.

Conflicts of Interest: The authors declare no conflict of interest.

\section{References}

1. Park, S.E. Epidemiology, virology, and clinical features of severe acute respiratory syndrome-coronavirus-2 (SARS-CoV-2; Coronavirus Disease-19). Clin. Exp. Pediatrics 2020, 63, 119. [CrossRef] [PubMed]

2. Coronavirus Disease 2019 (COVID-19): Situation Report, 147. Data as Received by WHO from National Authorities by 10:00 CEST, 15 June 2020. Available online: https:/ / www.who.int/docs/default-source/coronaviruse/situation-reports / 20200615 -covid-19-sitrep-147.pdf?sfvrsn=2497a605_4 (accessed on 26 February 2021).

3. Nishiura, H.; Kobayashi, T.; Miyama, T.; Suzuki, A.; Jung, S.; Hayashi, K.; Kinoshita, R.; Yang, Y.; Yuan, B.; Akhmetzhanov, A.R. Estimation of the asymptomatic ratio of novel coronavirus infections (COVID-19). Int. J. Infect. Dis. 2020, 94, 154-155. [CrossRef] [PubMed]

4. SARS-COV-2 Diagnostic Pipeline. Available online: https://www.finddx.org/ covid-19/pipeline/?avance=In+development\& type=all\&test_target=all\&status=all\&section=show-all\&action=default\#diag_tab (accessed on 20 September 2020).

5. Kakhki, R.K.; Kakhki, M.K.; Neshani, A. COVID-19 target: A specific target for novel coronavirus detection. Gene Rep. 2020, 20, 100740. [CrossRef] [PubMed]

6. Wu, A.; Peng, Y.; Huang, B.; Ding, X.; Wang, X.; Niu, P.; Meng, J.; Zhu, Z.; Zhang, Z.; Wang, J. Genome composition and divergence of the novel coronavirus (2019-nCoV) originating in China. Cell Host Microbe 2020, 27, 325-328. [CrossRef] [PubMed]

7. Clarke, N.E.; Hooper, N.M.; Turner, A.J. Angiotensin-converting enzyme-2. Handb. Proteolytic Enzym. 2013, 499-504. [CrossRef]

8. Wrapp, D.; Wang, N.; Corbett, K.S.; Goldsmith, J.A.; Hsieh, C.-L.; Abiona, O.; Graham, B.S.; McLellan, J.S. Cryo-EM structure of the 2019-nCoV spike in the prefusion conformation. Science 2020, 367, 1260-1263. [CrossRef]

9. Hasöksüz, M.; Kiliç, S.; Saraç, F. Coronaviruses and SARS-COV-2. Turk. J. Med. Sci. 2020, 50, 549-556. [CrossRef]

10. Schoeman, D.; Fielding, B.C. Coronavirus envelope protein: Current knowledge. Virol. J. 2019, 16, 69. [CrossRef] [PubMed]

11. Lu, R.; Zhao, X.; Li, J.; Niu, P.; Yang, B.; Wu, H.; Wang, W.; Song, H.; Huang, B.; Zhu, N. Genomic characterisation and epidemiology of 2019 novel coronavirus: Implications for virus origins and receptor binding. Lancet 2020, 395, 565-574. [CrossRef]

12. Cristina, S.; Concetta, R.; Francesco, R.; Annalisa, C. SARS-Cov-2 infection: Response of human immune system and possible implications for the rapid test and treatment. Int. Immunopharmacol. 2020, 84, 106519.

13. Wang, Z.; Ye, D.; Wang, M.; Zhao, M.; Li, D.; Ye, J.; Liu, J.; Xu, Y.; Zhang, J.; Pan, W. Clinical Features of COVID-19 Patients with Different Outcomes in Wuhan: A Retrospective Observational Study. BioMed Res. Int. 2020, 2020, 1-10. [CrossRef]

14. Fan, Z.; Chen, L.; Li, J.; Cheng, X.; Yang, J.; Tian, C.; Zhang, Y.; Huang, S.; Liu, Z.; Cheng, J. Clinical features of COVID-19-related liver functional abnormality. Clin. Gastroenterol. Hepatol. 2020, 18, 1561-1566. [CrossRef]

15. Abbott, T.R.; Dhamdhere, G.; Liu, Y.; Lin, X.; Goudy, L.; Zeng, L.; Chemparathy, A.; Chmura, S.; Heaton, N.S.; Debs, R. Development of CRISPR as an antiviral strategy to combat SARS-CoV-2 and influenza. Cell 2020, 181, 865-876.e12. [CrossRef]

16. Laboratory Testing for Coronavirus Disease (COVID-19) in Suspected Human Cases: Interim Guidance, 19 March 2020. Available online: https: / /apps.who.int/iris/handle/10665/331501 (accessed on 19 March 2021).

17. Xiao, A.T.; Tong, Y.X.; Zhang, S. False negative of RT-PCR and prolonged nucleic acid conversion in COVID-19: Rather than recurrence. J. Med. Virol. 2020, 92, 1755-1756. [CrossRef]

18. SARS-CoV-2 Reference Panel Comparative Data. Available online: https://www.fda.gov/medical-devices/coronavirus-covid19-and-medical-devices/sars-cov-2-reference-panel-comparative-data (accessed on 31 March 2021).

19. Tahmasebi, S.; Khosh, E.; Esmaeilzadeh, A. The outlook for diagnostic purposes of the 2019-novel coronavirus disease. J. Cell. Physiol. 2020, 235, 9211-9229. [CrossRef]

20. Qu, J.; Wu, C.; Li, X.; Zhang, G.; Jiang, Z.; Li, X.; Zhu, Q.; Liu, L. Profile of immunoglobulin G and IgM antibodies against severe acute respiratory syndrome coronavirus 2 (SARS-CoV-2). Clin. Infect. Dis. 2020, 71, 2255-2258. [CrossRef] [PubMed]

21. Jacofsky, D.; Jacofsky, E.M.; Jacofsky, M. Understanding antibody testing for COVID-19. J. Arthroplast. 2020, 35, S74-S81. [CrossRef] [PubMed]

22. Xiang, F.; Wang, X.; He, X.; Peng, Z.; Yang, B.; Zhang, J.; Zhou, Q.; Ye, H.; Ma, Y.; Li, H. Antibody detection and dynamic characteristics in patients with COVID-19. Clin. Infect. Dis. 2020, 71, 1930-1934. [CrossRef] [PubMed] 
23. Zhang, W.; Du, R.-H.; Li, B.; Zheng, X.-S.; Yang, X.-L.; Hu, B.; Wang, Y.-Y.; Xiao, G.-F.; Yan, B.; Shi, Z.-L. Molecular and serological investigation of 2019-nCoV infected patients: Implication of multiple shedding routes. Emerg. Microbes Infect. 2020, 9, 386-389. [CrossRef] [PubMed]

24. Fang, X.; Mei, Q.; Yang, T.; Li, L.; Wang, Y.; Tong, F.; Geng, S.; Pan, A. Low-dose corticosteroid therapy does not delay viral clearance in patients with COVID-19. J. Infect. 2020, 81, 147-178. [CrossRef] [PubMed]

25. Ma, H.; Zeng, W.; He, H.; Zhao, D.; Jiang, D.; Zhou, P.; Cheng, L.; Li, Y.; Ma, X.; Jin, T. Serum IgA, IgM, and IgG responses in COVID-19. Cell. Mol. Immunol. 2020, 17, 773-775. [CrossRef] [PubMed]

26. Kontou, P.I.; Braliou, G.G.; Dimou, N.L.; Nikolopoulos, G.; Bagos, P.G. Antibody tests in detecting SARS-CoV-2 infection: A meta-analysis. Diagnostics 2020, 10, 319. [CrossRef] [PubMed]

27. Cinquanta, L.; Fontana, D.E.; Bizzaro, N. Chemiluminescent immunoassay technology: What does it change in autoantibody detection? Autoimmun. Highlights 2017, 8, 9. [CrossRef]

28. Zhao, J.; Yuan, Q.; Wang, H.; Liu, W.; Liao, X.; Su, Y.; Wang, X.; Yuan, J.; Li, T.; Li, J. Antibody responses to SARS-CoV-2 in patients with novel coronavirus disease 2019. Clin. Infect. Dis. 2020, 71, 2027-2034. [CrossRef]

29. Martinaud, C.; Hejl, C.; Igert, A.; Bigaillon, C.; Bonnet, C.; Mérens, A.; Wolf, A.; Foissaud, V.; Leparc-Goffart, I. Evaluation of the Quotient ${ }^{\circledR M}$ MosaiQ ${ }^{\mathrm{TM}}$ COVID-19 antibody microarray for the detection of IgG and IgM antibodies to SARS-CoV-2 virus in humans. J. Clin. Virol. 2020, 130, 104571. [CrossRef]

30. Sethuraman, N.; Jeremiah, S.S.; Ryo, A. Interpreting diagnostic tests for SARS-CoV-2. JAMA 2020, 323, 2249-2251. [CrossRef]

31. Bahadır, E.B.; Sezgintürk, M.K. Lateral flow assays: Principles, designs and labels. TrAC Trends Anal. Chem. 2016, 82, 286-306. [CrossRef]

32. Gan, S.D.; Patel, K.R. Enzyme immunoassay and enzyme-linked immunosorbent assay. J. Investig. Derm. 2013, 133, e12. [CrossRef]

33. Ahmed, S.; Ning, J.; Peng, D.; Chen, T.; Ahmad, I.; Ali, A.; Lei, Z.; Abu bakr Shabbir, M.; Cheng, G.; Yuan, Z. Current advances in immunoassays for the detection of antibiotics residues: A review. Food Agric. Immunol. 2020, 31, 268-290. [CrossRef]

34. Zhao, L.; Sun, L.; Chu, X. Chemiluminescence immunoassay. TrAC Trends Anal. Chem. 2009, 28, 404-415. [CrossRef]

35. Espejo, A.P.; Akgun, Y.; Al Mana, A.F.; Tjendra, Y.; Millan, N.C.; Gomez-Fernandez, C.; Cray, C. Review of current advances in serologic testing for COVID-19. Am. J. Clin. Pathol. 2020, 154, 293-304. [CrossRef]

36. Bryan, A.; Pepper, G.; Wener, M.H.; Fink, S.L.; Morishima, C.; Chaudhary, A.; Jerome, K.R.; Mathias, P.C.; Greninger, A.L. Performance characteristics of the Abbott Architect SARS-CoV-2 IgG assay and seroprevalence in Boise, Idaho. J. Clin. Microbiol. 2020, 58. [CrossRef]

37. Xu, Y.; Xu, Z.; Liu, X.; Cai, L.; Zheng, H.; Huang, Y.; Zhou, L.; Huang, L.; Lin, Y.; Deng, L. Clinical findings in critical ill patients infected with SARS-Cov-2 in Guangdong Province, China: A multi-center, retrospective, observational study. medRxiv 2020. [CrossRef]

38. Vashist, S.K. In Vitro Diagnostic Assays for COVID-19: Recent Advances and Emerging Trends; Multidisciplinary Digital Publishing Institute: Basel, Switzerland, 2020.

39. Infantino, M.; Grossi, V.; Lari, B.; Bambi, R.; Perri, A.; Manneschi, M.; Terenzi, G.; Liotti, I.; Ciotta, G.; Taddei, C. Diagnostic accuracy of an automated chemiluminescent immunoassay for anti-SARS-CoV-2 IgM and IgG antibodies: An Italian experience. J. Med. Virol. 2020, 92, 1671-1675. [CrossRef]

40. Long, Q.X.; Liu, B.Z.; Deng, H.J.; Wu, G.C.; Deng, K.; Chen, Y.K. Antibody responses to SARS-CoV-2 in patients with COVID-19. Nat. Med. 2020, 26, 845-848. [CrossRef]

41. Cai, X.; Chen, J.; Hu, J.; Long, Q.; Deng, H.; Fan, K.; Liao, P.; Liu, B.; Wu, G.; Chen, Y. A Peptide-based Magnetic Chemiluminescence Enzyme Immunoassay for Serological Diagnosis of Corona Virus Disease 2019 (COVID-19). Int. J. Infect. Dis. 2020, 222, 189-193. [CrossRef]

42. Lin, D.; Liu, L.; Zhang, M.; Hu, Y.; Yang, Q.; Guo, J.; Dai, Y.; Xu, Y.; Cai, Y.; Chen, X. Evaluations of serological test in the diagnosis of 2019 novel coronavirus (SARS-CoV-2) infections during the COVID-19 outbreak. Eur. J. Clin. Microbiol. Infect. Dis. 2020, 39, 2271-2277. [CrossRef]

43. Jin, Y.; Wang, M.; Zuo, Z.; Fan, C.; Ye, F.; Cai, Z.; Wang, Y.; Cui, H.; Pan, K.; Xu, A. Diagnostic value and dynamic variance of serum antibody in coronavirus disease 2019. Int. J. Infect. Dis. 2020, 94, 49-52. [CrossRef]

44. EUA Authorized Serology Test Performance. Available online: https://www.fda.gov/medical-devices/coronavirus-disease-2019 -covid-19-emergency-use-authorizations-medical-devices/eua-authorized-serology-test-performance (accessed on 5 April 2021).

45. Lequin, R.M. Enzyme immunoassay (EIA)/enzyme-linked immunosorbent assay (ELISA). Clin. Chem. 2005, 51, 2415-2418. [CrossRef]

46. Shah, K.; Maghsoudlou, P. Enzyme-linked immunosorbent assay (ELISA): The basics. Br. J. Hosp. Med. 2016, 77, C98-C101. [CrossRef]

47. Du, B.; Wen, F.; Guo, X.; Zheng, N.; Zhang, Y.; Li, S.; Zhao, S.; Liu, H.; Meng, L.; Xu, Q. Evaluation of an ELISA-based visualization microarray chip technique for the detection of veterinary antibiotics in milk. Food Control 2019, 106, 106713. [CrossRef]

48. Dahlke, C.; Heidepriem, J.; Kobbe, R.; Santer, R.; Koch, T.; Fathi, A.; Ly, M.L.; Schmiedel, S.; Seeberger, P.H.; Addo, M.M. Distinct early IgA profile may determine severity of COVID-19 symptoms: An immunological case series. medRxiv 2020. [CrossRef]

49. Amanat, F.; Stadlbauer, D.; Strohmeier, S.; Nguyen, T.H.; Chromikova, V.; McMahon, M.; Jiang, K.; Arunkumar, G.A.; Jurczyszak, D.; Polanco, J. A serological assay to detect SARS-CoV-2 seroconversion in humans. Nat. Med. 2020, 26, 1033-1036. [CrossRef] 
50. Okba, N.M.; Muller, M.A.; Li, W.; Wang, C.; GeurtsvanKessel, C.H.; Corman, V.M.; Lamers, M.M.; Sikkema, R.S.; de Bruin, E.; Chandler, F.D. SARS-CoV-2 specific antibody responses in COVID-19 patients. Nat. Med. 2020, 26, 845-848.

51. Zhang, P.; Gao, Q.; Wang, T.; Ke, Y.; Mo, F.; Jia, R.; Liu, W.; Liu, L.; Zheng, S.; Liu, Y. Evaluation of recombinant nucleocapsid and spike proteins for serological diagnosis of novel coronavirus disease 2019 (COVID-19). MedRxiv 2020. [CrossRef]

52. In Vitro Diagnostics EUAs. Available online: https://www.fda.gov/medical-devices/coronavirus-disease-2019-covid-19 -emergency-use-authorizations-medical-devices/vitro-diagnostics-euas (accessed on 15 February 2021).

53. cPass $^{\text {TM }}$ SARS-CoV-2 Neutralization Antibody Detection Kit. Available online: https://www.fda.gov/media/143583/download (accessed on 14 February 2021).

54. Lassaunière, R.; Frische, A.; Harboe, Z.B.; Nielsen, A.C.; Fomsgaard, A.; Krogfelt, K.A.; Jørgensen, C.S. Evaluation of nine commercial SARS-CoV-2 immunoassays. Medrxiv 2020. [CrossRef]

55. Ching, L.; Chang, S.P.; Nerurkar, V.R. COVID-19 Special Column: Principles Behind the Technology for Detecting SARS-CoV-2, the Cause of COVID-19. Hawaii J. Health Soc. Welf. 2020, 79, 136.

56. Ambrose, J.H. Evaluation of a microsphere-based immunoassay (MIA) in measuring diagnostic and prognostic markers of dengue virus infection. Evaluation 2017.

57. Yang, H.S.; Racine-Brzostek, S.E.; Lee, W.T.; Hunt, D.; Yee, J.; Chen, Z.; Kubiak, J.; Cantu, M.; Hatem, L.; Zhong, E. SARSCoV-2 antibody characterization in emergency department, hospitalized and convalescent patients by two semi-quantitative immunoassays. Clin. Chim. Acta 2020, 509, 117-125. [CrossRef]

58. Adams, E.R.; Anand, R.; Andersson, M.I.; Auckland, K.; Baillie, J.K.; Barnes, E.; Bell, J.; Berry, T.; Bibi, S.; Carroll, M. Evaluation of antibody testing for SARS-Cov-2 using ELISA and lateral flow immunoassays. MedRxiv 2020. [CrossRef]

59. Rosenberg, E.S.; Tesoriero, J.M.; Rosenthal, E.M.; Chung, R.; Barranco, M.A.; Styer, L.M.; Parker, M.M.; Leung, S.-Y.J.; Morne, J.; Greene, D. Cumulative incidence and diagnosis of SARS-CoV-2 infection in New York. Ann. Epidemiol. 2020, 48, 23-29.e4. [CrossRef] [PubMed]

60. Fong, C.H.-Y.; Cai, J.-P.; Dissanayake, T.K.; Chen, L.-L.; Choi, C.Y.-K.; Wong, L.-H.; Ng, A.C.-K.; Pang, P.K.; Ho, D.T.-Y.; Poon, R.W.S. Improved Detection of Antibodies against SARS-CoV-2 by Microsphere-Based Antibody Assay. Int. J. Mol. Sci. 2020, $21,6595$. [CrossRef] [PubMed]

61. Zhang, M.; Sheng, Y. An indirect competitive fluorescence immunoassay for determination of dicyclohexyl phthalate in water samples. J. Fluoresc. 2010, 20, 1167-1173. [CrossRef] [PubMed]

62. Hicks, J.M. Fluorescence immunoassay. Hum. Pathol. 1984, 15, 112-116. [CrossRef]

63. Rowland, R.R. Serological Approach for Diagnosis and Surveillance of Multiple Agents in Serum and Oral Fluid Samples. Available online: https:/ / porkcheckoff.org/research/serological-approach-for-diagnosis-and-surveillance-of-multiple-agentsin-serum-and-oral-fluid-samples/ (accessed on 2 March 2021).

64. Langenhorst, R.J.; Lawson, S.; Kittawornrat, A.; Zimmerman, J.J.; Sun, Z.; Li, Y.; Christopher-Hennings, J.; Nelson, E.A.; Fang, Y. Development of a fluorescent microsphere immunoassay for detection of antibodies against porcine reproductive and respiratory syndrome virus using oral fluid samples as an alternative to serum-based assays. Clin. Vaccine Immunol. 2012, 19, 180-189. [CrossRef]

65. Okda, F.; Liu, X.; Singrey, A.; Clement, T.; Nelson, J.; Christopher-Hennings, J.; Nelson, E.A.; Lawson, S. Development of an indirect ELISA, blocking ELISA, fluorescent microsphere immunoassay and fluorescent focus neutralization assay for serologic evaluation of exposure to North American strains of Porcine Epidemic Diarrhea Virus. BMC Vet. Res. 2015, 11, 1-14. [CrossRef]

66. New York SARS-CoV Microsphere Immunoassay for Antibody Detection. Available online: https://www.fda.gov/media/1375 40 / download (accessed on 20 September 2020).

67. xMAP®SARS-CoV-2 Antibody Testing. Available online: https://www.luminexcorp.com/xmap-sars-cov-2-antibody-testing/ \#overview (accessed on 4 March 2021).

68. ichromxTM COVID-19 Ab from Boditech. Available online: http://www.boditech.co.kr/eng/common/asp/download.asp?file= /board/NEWS/ichroma\%E2\%84\%A2_COVID-19_Ab_(with_ichroma\%E2\%84\%A2_II_Reader)_test_system.pdf\&target=TB_ BOARD_ALL\&num=2883 (accessed on 2 March 2021).

69. Serology Test Evaluation Report for "GenBody COVID-19 IgM/IgG" from GenBody Inc. Available online: https://www. accessdata.fda.gov/cdrh_docs/presentations/maf/maf3300-a001.pdf (accessed on 20 September 2020).

70. ichroma COVID-19 Ab by Boditech Med Inc. Available online: https://covid19innovationhub.org/innovation/ichroma-covid19-ab (accessed on 4 March 2021).

71. Lauer, S.A.; Grantz, K.H.; Bi, Q.; Jones, F.K.; Zheng, Q.; Meredith, H.R.; Azman, A.S.; Reich, N.G.; Lessler, J. The incubation period of coronavirus disease 2019 (COVID-19) from publicly reported confirmed cases: Estimation and application. Ann. Intern. Med. 2020, 172, 577-582. [CrossRef]

72. Boldog, P.; Tekeli, T.; Vizi, Z.; Dénes, A.; Bartha, F.A.; Röst, G. Risk assessment of novel coronavirus COVID-19 outbreaks outside China. J. Clin. Med. 2020, 9, 571. [CrossRef]

73. Machado, B.A.S.; Hodel, K.V.S.; Barbosa-Júnior, V.G.; Soares, M.B.P.; Badaró, R. The Main Molecular and Serological Methods for Diagnosing COVID-19: An Overview Based on the Literature. Viruses 2021, 13, 40. [CrossRef]

74. Fang, C.; Chen, Z.; Li, L.; Xia, J. Barcode lateral flow immunochromatographic strip for prostate acid phosphatase determination. J. Pharm. Biomed. Anal. 2011, 56, 1035-1040. [CrossRef] 
75. Mboowa, G. Current and emerging diagnostic tests available for the novel COVID-19 global pandemic. AAS Open Res. 2020 , 3, 8. [CrossRef]

76. Koczula, K.M.; Gallotta, A. Lateral flow assays. Essays Biochem. 2016, 60, 111-120.

77. Anfossi, L.; Di Nardo, F.; Cavalera, S.; Giovannoli, C.; Baggiani, C. Multiplex lateral flow immunoassay: An overview of strategies towards high-throughput point-of-need testing. Biosensors 2019, 9, 2. [CrossRef]

78. Mao, X.; Baloda, M.; Gurung, A.S.; Lin, Y.; Liu, G. Multiplex electrochemical immunoassay using gold nanoparticle probes and immunochromatographic strips. Electrochem. Commun. 2008, 10, 1636-1640. [CrossRef]

79. Mao, X.; Wang, W.; Du, T.-E. Rapid quantitative immunochromatographic strip for multiple proteins test. Sens. Actuators B Chem. 2013, 186, 315-320. [CrossRef]

80. Huang, C.; Wen, T.; Shi, F.-J.; Zeng, X.-Y.; Jiao, Y.-J. Rapid Detection of IgM Antibodies against the SARS-CoV-2 Virus via Colloidal Gold Nanoparticle-Based Lateral-Flow Assay. ACS Omega 2020, 5, 12550-12556. [CrossRef] [PubMed]

81. Chen, Z.; Zhang, Z.; Zhai, X.; Li, Y.; Lin, L.; Zhao, H.; Bian, L.; Li, P.; Yu, L.; Wu, Y. Rapid and Sensitive Detection of antiSARS-CoV-2 IgG, Using Lanthanide-Doped Nanoparticles-Based Lateral Flow Immunoassay. Anal. Chem. 2020, 92, 7226-7231. [CrossRef]

82. TBG SARS-CoV-2 IgG/IgM Rapid Test Kit Cat. No. 20010, Instruction for Use. Available online: https://www.fda.gov/media/ 141773/download (accessed on 5 April 2021).

83. COVID-19 Assay Kit: COVID 19 IgG/IgM Coronavirus Assay Kit. Available online: https://www.mybiosource.com/covid-19 -assay-kits / covid-19-igg-igm-coronavirus/7135927 (accessed on 20 November 2020).

84. COVID-19 IgM/IgG Rapid Test. Available online: https://www.biomedomics.com/products/infectious-disease/covid-19-rt/ (accessed on 20 November 2020).

85. SARS-CoV-2 Rapid Test. Available online: https://www.pharmact.eu/ (accessed on 20 September 2020).

86. RapCov ${ }^{\mathrm{TM}}$ Rapid COVID-19 Test-FDA. Available online: https://www.fda.gov/media/145080/download (accessed on 5 April 2021).

87. WANTAI SARS-CoV-2 Ab Rapid Test. Available online: https://www.fda.gov/media/140030/download (accessed on 5 April 2021).

88. SiennaTM-Clarity COVIBLOCK ${ }^{\mathrm{TM}}$ COVID-19 lgG/lgM Rapid Test Cassette. Available online: https://www.fda.gov/media/14 0082/ download (accessed on 5 April 2021).

89. BIOTIME SARS-CoV-2 IgG/IgM Rapid Qualitative Test-FDA. Available online: https://www.fda.gov/media/140443 / download (accessed on 5 April 2021).

90. COVID-19 IgG/IgM Rapid Test Cassette-FDA. Available online: https://www.fda.gov/media/138438/download (accessed on 5 April 2021).

91. IgM/IgG Antibody Combo Test Kit—FDA. Available online: https://www.fda.gov/media/139409/download (accessed on 5 April 2021).

92. RightSign COVID-19 IgG/IgM Rapid Test Cassette-FDA. Available online: https://www.fda.gov/media/138660/download (accessed on 5 April 2021).

93. Rapid COVID-19 IgM/IgG Combo Test Kit-FDA. Available online: https://www.fda.gov/media/140297/download (accessed on 5 April 2021).

94. Biohit SARS-CoV-2 IgM/IgG Antibody Test Kit-FDA. Available online: https://www.fda.gov/media/139283/download (accessed on 5 April 2021).

95. Assure COVID-19 IgG/IgM Rapid Test Device-FDA. Available online: https://www.fda.gov/media/139792/download\#: \{\}: text $=$ The $\% 20$ Assure $\% 20$ COVID $\% 2 D 19 \% 20 I g G, E D T A) \% 20$ and $\% 20$ fingerstick\%20whole\%20blood (accessed on 5 April 2021).

96. Cellex-FDA. Available online: https:/ / www.fda.gov/media/136625/download (accessed on 20 March 2020).

97. IgG/IgM Antibody Test—FDA. Available online: https://www.fda.gov/media/141550/download\#: \{\}:text=The\%20Tell\%20 Me\%20Fast\%20Novel, whole\%20blood\%20(Lithium\%2DHeparin\%2C (accessed on 5 April 2021).

98. Chembio Announces Launch of DPP COVID-19 Serological Point-of-Care Test. Available online: https://www.globenewswire com/fr/news-release/2020/04/01/2009684/0/en/Chembio-Announces-Launch-of-DPP-COVID-19-Serological-Point-ofCare-Test.html (accessed on 17 December 2020).

99. Kalsi, S.; Valiadi, M.; Tsaloglou, M.-N.; Parry-Jones, L.; Jacobs, A.; Watson, R.; Turner, C.; Amos, R.; Hadwen, B.; Buse, J. Rapid and sensitive detection of antibiotic resistance on a programmable digital microfluidic platform. Lab A Chip 2015, 15, 3065-3075. [CrossRef]

100. Netherlands Becomes Latest Country to Reject China-Made Coronavirus Test Kits, Gear. Available online: https:/ / www.foxnews. $\mathrm{com} /$ world/netherlands-becomes-latest-country-to-reject-china-made-coronavirus-test-kits-gear (accessed on 5 April 2021).

101. $80 \%$ of Rapid COVID-19 Tests the Czech Republic Bought From China are Wrong. Available online: https://praguemorning.cz/ 80-of-rapid-covid-19-tests-the-czech-republic-bought-from-china-are-wrong/ (accessed on 5 April 2021).

102. Spain, Europe'sWorst-Hit Country after Italy, Says Coronavirus Tests It Bought from China are Failing to Detect Positive Cases. Available online: https:/ / www.businessinsider.in/science/news/spain-europes-worst-hit-country-after-italy-says-coronavirustests-it-bought-from-china-are-failing-to-detect-positive-cases/articleshow/74832667.cms (accessed on 5 April 2021).

103. China Supplied Faulty Coronavirus Test Kits to Spain, Czech Republic. Available online: https://news.yahoo.com/chinasupplied-faulty-coronavirus-test-162306412.html (accessed on 5 April 2021). 
104. Wingren, C.; Borrebaeck, C.A. Antibody-based microarrays. In Microchip Methods in Diagnostics; Springer: Berlin/Heidelberg, Germany, 2009; pp. 57-84.

105. Jiang, H.; Li, Y.; Zhang, H.; Wang, W.; Yang, X.; Qi, H.; Li, H.; Men, D.; Zhou, J.; Tao, S. SARS-CoV-2 proteome microarray for global profiling of COVID-19 specific IgG and IgM responses. Nat. Commun. 2020, 11, 1-11. [CrossRef]

106. Wang, H.; Hou, X.; Wu, X.; Liang, T.; Zhang, X.; Wang, D.; Teng, F.; Dai, J.; Duan, H.; Guo, S. SARS-CoV-2 proteome microarray for mapping COVID-19 antibody interactions at amino acid resolution. bioRxiv 2020, 6, 2238-2249. [CrossRef]

107. Sanchez-Carbayo, M. Antibody microarrays as tools for biomarker discovery. In Protein Microarrays; Springer: Berlin/Heidelberg, Germany, 2011; pp. 159-182.

108. Jiang, H.; Li, Y.; Zhang, H.; Wang, W.; Men, D.; Yang, X.; Qi, H.; Zhou, J.; Tao, S. Global profiling of SARS-CoV-2 specific IgG/IgM responses of convalescents using a proteome microarray. medRxiv 2020. [CrossRef]

109. Mosaiq ${ }^{\mathrm{TM}}$ by Quotient the Mosaiq Covid-19 Antibody Microarray. Available online: https://quotientbd.com/covid-19\#: \{\}:text= The \%20MosaiQ\%20COVID\%2D19\%20Antibody\%20Microarray\%20is\%20designed \%20as\%20a, at \%20SARS\%2DCoV\%2D2. (accessed on 21 September 2020).

110. Quotient Limited Reports Impressive Results from an Independent SARS-CoV-2 Antibody Detection Study Conducted in Spain. Quotient Limited Company. 20 July 2020. Available online: https://www.globenewswire.com/news-release/2020/07/20/2 064203/0/en/Quotient-Limited-Reports-Impressive-Results-from-an-Independent-SARS-CoV-2-Antibody-Detection-StudyConducted-in-Spain.html (accessed on 5 April 2021).

111. Kohmer, N.; Westhaus, S.; Rühl, C.; Ciesek, S.; Rabenau, H.F. Brief clinical evaluation of six high-throughput SARS-CoV-2 IgG antibody assays. J. Clin. Virol. 2020, 104480. [CrossRef]

112. Tang, M.S.; Hock, K.G.; Logsdon, N.M.; Hayes, J.E.; Gronowski, A.M.; Anderson, N.W.; Farnsworth, C.W. Clinical performance of two SARS-CoV-2 serologic assays. Clin. Chem. 2020, 66, 1055-1062. [CrossRef]

113. ECDC. An Overview of the Rapid Test Situation for COVID-19 Diagnosis in the EU/EEA; ECDC: Solna, Switzerland, 2020.

114. PEPperCHIP®SARS-CoV-2 Proteome Microarray. Available online: https://www.pepperprint.com/products/pepperchiprstandard-microarrays / pepperchipr-sars-cov-2-proteome-microarray /\#: \{ \}:text=PEPperCHIP\%C2\%AE \%20SARS \%2DCoV\% 2D2\%20Proteome\%20Microarray\&text=In\%20light\%20of\%20the\%20ongoing,CoV\%2D2)\%20viral\%20genome (accessed on 5 April 2021).

115. 1PEPperCHIP®SARS CoV Antigen Microarray. Available online: http://www.biocat.com/bc/pdf/PEPperCHIP_SARS-CoV_ Antigen_Microarray.pdf (accessed on 5 April 2021).

116. PEPperCHIP®Pan-Corona Spike Protein Microarray. Available online: https://www.pepperprint.com/products/pepperchiprstandard-microarrays / pepperchipr-pan-corona-spike-protein-microarray/ (accessed on 5 April 2021).

117. pGOLD ${ }^{\mathrm{TM}}$ COVID-19 High Accuracy IgG/IgM Assay. Available online: https://www.nirmidas.com/pgold-covid-19-igg-igmassay-kit (accessed on 5 April 2021).

118. Immusafe COVID Test Brochure-Sengenics. Available online: https://www.sengenics.com/wp-content/uploads/2020/05/ IMMUSAFE-COVID-TEST-BROCHURE.pdf (accessed on 5 April 2021).

119. ImmuSAFE Biochip. Available online: https://sengenics.com/immusafe-covid-test/ (accessed on 5 April 2021).

120. Viral Protein Array-Sino Biological. Available online: https://www.sinobiological.com/research/virus/coronavirus-array (accessed on 19 February 2020).

121. Zhu, H.; Zhang, H.; Ni, S.; Korabečná, M.; Yobas, L.; Neuzil, P. The vision of point-of-care PCR tests for the COVID-19 pandemic and beyond. TrAC Trends Anal. Chem. 2020, 130, 115984. [CrossRef]

122. Azkur, A.K.; Akdis, M.; Azkur, D.; Sokolowska, M.; van de Veen, W.; Brüggen, M.C.; O’Mahony, L.; Gao, Y.; Nadeau, K.; Akdis, C.A. Immune response to SARS-CoV-2 and mechanisms of immunopathological changes in COVID-19. Allergy 2020, 75, 1564-1581. [CrossRef]

123. To, K.K.-W.; Tsang, O.T.-Y.; Leung, W.-S.; Tam, A.R.; Wu, T.-C.; Lung, D.C.; Yip, C.C.-Y.; Cai, J.-P.; Chan, J.M.-C.; Chik, T.S.-H. Temporal profiles of viral load in posterior oropharyngeal saliva samples and serum antibody responses during infection by SARS-CoV-2: An observational cohort study. Lancet Infect. Dis. 2020, 20, 565-574. [CrossRef]

124. Coronavirus Disease 2019 Testing Basics. Available online: https:/ /www.fda.gov/ consumers/consumer-updates/coronavirusdisease-2019-testing-basics (accessed on 5 April 2021).

125. Goudouris, E.S. Laboratory diagnosis of COVID-19. J. De Pediatr. 2021, 97, 7-12. [CrossRef]

126. Coronavirus (COVID-19) Update: FDA Authorizes First Antigen Test to Help in the Rapid Detection of the Virus that Causes COVID-19 in Patients. Available online: https://www.fda.gov/news-events/press-announcements/coronavirus-covid-19 -update-fda-authorizes-first-antigen-test-help-rapid-detection-virus-causes (accessed on 21 September 2020).

127. Lukić, V. Laboratory information system—where are we today? J. Med. Biochem. 2017, 36, 220. [CrossRef]

128. Sofia SARS Antigen FIA / Quidel. Available online: https://www.quidel.com/immunoassays/rapid-sars-tests/sofia-sarsantigen-fia (accessed on 4 March 2021).

129. Sofia 2 Flu + SARS Antigen FIA. Available online: https://www.quidel.com/immunoassays/sofia-2-flu-sars-antigen-fia\#: $\{\{$ : text=The $\% 20$ Sofia $\% 202 \% 20 \mathrm{Flu} \% 20 \% 2 \mathrm{~B} \% 20 \mathrm{SARS}$, and $\% 20$ SARS $\% 2 \mathrm{DCoV} \% 2 \mathrm{D} 2$ (accessed on 9 October 2020).

130. BD Veritor ${ }^{\mathrm{TM}}$ Plus System for Rapid COVID-19 (SARS-CoV-2) Testing. Available online: https://www.bd.com/en-us/offerings/ capabilities / microbiology-solutions / point-of-care-testing/bd-veritor-plus-system-for-rapid-covid-19-sars-cov-2-testing (accessed on 5 March 2021). 
131. BD Veritor System for Rapid Detection of SARS-CoV-2_FDA. Available online: https://www.fda.gov/media/139755/download (accessed on 21 September 2020).

132. BinaxNOWTM COVID-19 Ag CARD HOME TEST-FDA. Available online: https://www.fda.gov/media/144574/download (accessed on 5 April 2021).

133. Coronavirus (COVID-19) Update: FDA Authorizes Antigen Test as First Over-the-Counter Fully At-Home Diagnostic Test for COVID-19. Available online: https:/ / www.fda.gov/news-events/press-announcements/coronavirus-covid-19-update-fdaauthorizes-antigen-test-first-over-counter-fully-home-diagnostic (accessed on 5 April 2021).

134. CareStart COVID-19 Antigen test-FDA. Available online: https://www.fda.gov/media/142919/download (accessed on 5 April 2021).

135. Status ${ }^{\mathrm{TM}}$ COVID-19/Flu_Princeton BioMeditech Corporation. Available online: http://www.pbmc.com/downloads/Status_ Cov_Flu_EUA210015_IFU_P-5382.pdf (accessed on 5 April 2021).

136. Sampinute ${ }^{\mathrm{TM}}$ COVID-19 Antigen MIA-FDA. Available online: https://www.fda.gov/media/143270/download (accessed on 5 April 2021).

137. SimoaTM SARS-CoV-2 N Protein Antigen Test-FDA. Available online: https://www.fda.gov/media/144929/download (accessed on 5 April 2021).

138. Available online: https://www.fda.gov/media/144256/download (accessed on 5 April 2021).

139. BinaxNOW ${ }^{\mathrm{TM}}$ COVID-19 Ag Card-FDA. Available online: https://www.fda.gov/media/141570/download (accessed on 5 April 2021).

140. LumiraDx SARS-CoV-2 Ag Test-FDA. Available online: https://www.fda.gov/media/141304/download (accessed on 5 April 2021).

141. Sofia 2 Flu + SARS Antigen FIA-FDA. Available online: https://www.fda.gov/media/142704/download (accessed on 5 April 2021).

142. Lin, Q.; Wen, D.; Wu, J.; Liu, L.; Wu, W.; Fang, X.; Kong, J. Microfluidic immunoassays for sensitive and simultaneous detection of IgG/IgM/antigen of SARS-CoV-2 within 15 min. Anal. Chem. 2020, 92, 9454-9458. [CrossRef]

143. COVID-19 SARS-CoV-2 Antigen Test. Available online: https://www.lumiradx.com/us-en/what-we-do/diagnostics/testtechnology / antigen-test (accessed on 8 January 2021).

144. Abbott's Fast, \$5, 15-Minute, Easy-to-Use COVID-19 Antigen Test Receives FDA Emergency Use Authorization; Mobile App Displays Test Results To Help Our Return to Daily Life; Ramping Production to 50 Million Tests a Month. Abbot: 2020. Available online: https://abbott.mediaroom.com/2020-08-26-Abbotts-Fast-5-15-Minute-Easy-to-Use-COVID-19-AntigenTest-Receives-FDA-Emergency-Use-Authorization-Mobile-App-Displays-Test-Results-to-Help-Our-Return-to-Daily-LifeRamping-Production-to-50-Million-Tests-a-Month (accessed on 16 February 2021).

145. Navica ${ }^{\mathrm{TM}}$ Mobile App and Binaxnow ${ }^{\mathrm{TM}}$ COVID-19 Ag Card. Available online: https://www.globalpointofcare.abbott/en/ product-details/navica-binaxnow-covid-19-us.html (accessed on 16 February 2021).

146. PCL COVID-19 Rapid FIA. Available online: http://pclchip.com/eng/sub_n4/4_6.php?mode=view\&number=813\&b_name= eng_notice\&page $=1$ (accessed on 16 February 2021).

147. Seo, G.; Lee, G.; Kim, M.J.; Baek, S.-H.; Choi, M.; Ku, K.B.; Lee, C.-S.; Jun, S.; Park, D.; Kim, H.G. Rapid detection of COVID-19 causative virus (SARS-CoV-2) in human nasopharyngeal swab specimens using field-effect transistor-based biosensor. ACS Nano 2020, 14, 5135-5142. [CrossRef]

148. Simoa SARS-CoV-2 N Protein Antigen Test. Available online: https:/ /www.fda.gov/media/144925/download (accessed on 16 February 2021).

149. ELLUME COVID-19 Home Test. Product Overview for Healthcare Professionals. Available online: https:/ /www.fda.gov/media/ 144592/download (accessed on 16 February 2021).

150. Choi, J.R. Development of Point-of-Care Biosensors for COVID-19. Front. Chem. 2020, 8, 517. [CrossRef]

151. Georgakilas, V.; Tiwari, J.N.; Kemp, K.C.; Perman, J.A.; Bourlinos, A.B.; Kim, K.S.; Zboril, R. Noncovalent functionalization of graphene and graphene oxide for energy materials, biosensing, catalytic, and biomedical applications. Chem. Rev. 2016, 116, 5464-5519. [CrossRef]

152. Li, Y.; Liu, L.; Liu, G. CRISPR/Cas multiplexed biosensing: A challenge or an insurmountable obstacle? Trends Biotechnol. 2019, 37, 792-795. [CrossRef]

153. Murugan, D.; Bhatia, H.; Sai, V.; Satija, J. P-FAB: A fiber-optic biosensor device for rapid detection of COVID-19. Trans. Indian Natl. Acad. Eng. 2020, 5, 211-215. [CrossRef]

154. Mavrikou, S.; Moschopoulou, G.; Tsekouras, V.; Kintzios, S. Development of a Portable, Ultra-Rapid and Ultra-Sensitive CellBased Biosensor for the Direct Detection of the SARS-CoV-2 S1 Spike Protein Antigen. Sensors 2020, 20, 3121. [CrossRef] [PubMed]

155. Rider, T.H.; Petrovick, M.S.; Nargi, F.E.; Harper, J.D.; Schwoebel, E.D.; Mathews, R.H.; Blanchard, D.J.; Bortolin, L.T.; Young, A.M.; Chen, J. AB cell-based sensor for rapid identification of pathogens. Science 2003, 301, 213-215. [CrossRef]

156. athSensors, Inc. Announced the Development of a SARS-CoV-2 Biosensor. Available online: https://pathsensors.com/psi-sarscov-2-biosensor/ (accessed on 5 March 2021).

157. Combating 2019-nCoV: Advanced Nanobiosensing Platforms for POC Global Diagnostics and Surveillance. Available online: https: / / cordis.europa.eu/project/id/101003544 (accessed on 5 March 2021). 
158. Hochreiter, B.; Pardo-Garcia, A.; Schmid, J.A. Fluorescent proteins as genetically encoded FRET biosensors in life sciences. Sensors 2015, 15, 26281-26314. [CrossRef]

159. Marx, V. Probes: FRET sensor design and optimization. Nat. Methods 2017, 14, 949-953. [CrossRef]

160. Liang, K.-H.; Chang, T.-J.; Wang, M.-L.; Tsai, P.-H.; Lin, T.-H.; Wang, C.-T.; Yang, D.-M. Novel biosensor platforms for the detection of coronavirus infection and severe acute respiratory syndrome coronavirus 2. J. Chin. Med. Assoc. 2020, 83, 701-703. [CrossRef]

161. Park, T.J.; Lee, S.-K.; Yoo, S.M.; Yang, S.-M.; Lee, S.Y. Development of reflective biosensor using fabrication of functionalized photonic nanocrystals. J. Nanosci. Nanotechnol. 2011, 11, 632-637. [CrossRef] 